\title{
Remote Monitoring of Processes That Shape Desert Surfaces: The Desert Winds Project
}

\section{U.S. GEOLOGICAL SURVEY BULLETIN 1634}





\section{Remote Monitoring of Processes That Shape Desert Surfaces: The Desert Winds Project}

BY J. F. MCCAULEY, C. S. BREED, P. J. HELM, G. H. BILLINGSLEY, D. J. MacKINNON, M. J. GROLIER, and $\mathrm{C}$. K. MCCAULEY

Acquisition and analysis of geometeorologic data

from remote satellite-relay stations

in different desert regions of Arizona

U.S. GEOLOGICAL SURVEY BULLETIN 1634 


\section{DEPARTMENT OF THE INTERIOR WILLIAM P. CLARK, Secretary \\ U.S. GEOLOGICAL SURVEY \\ Dallas L. Peck, Director}

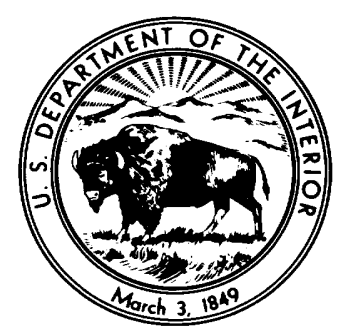

Library of Congress Catalog-Card No. 84-601115

UNITED STATES GOVERNMENT PRINTING OFFICE : 1984

For sale by the

Distribution Branch, Text Products Section

U.S. Geological Survey

604 South Pickett St.

Alexandria, VA 22304 


\section{CONTENTS}

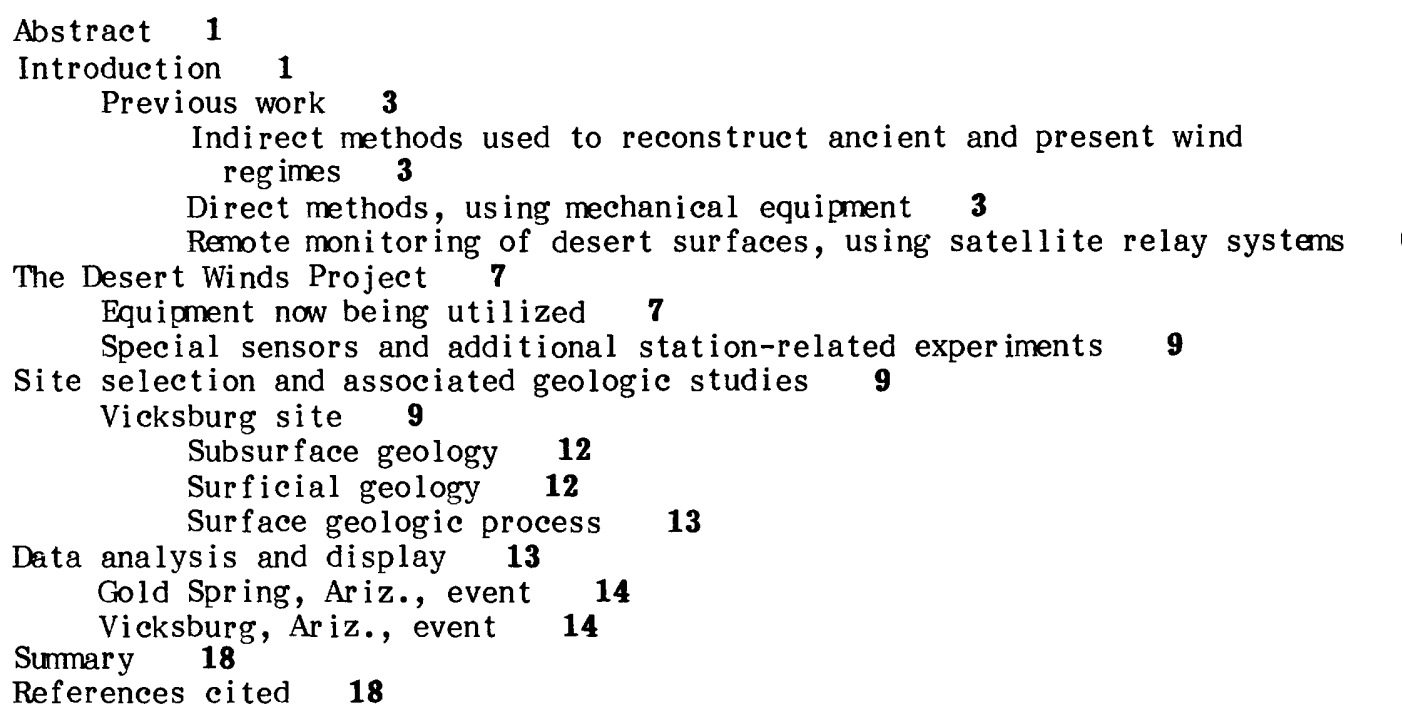

FIGURES

1. Schematic diagram of the data-acquisition and -transmission links for U.S. Geological Survey's Desert Winds Project 2

2. Photograph of wind-fluted and corraded "Nubian" or thoquartzite from top of the Gilf Kebir Plateau, southwestern Egypt 4

3 . Photograph of wind-etched and - fluted ventifact of white crystalline 1 imestone (Thebes Limestone of Eocene age) from the Limestone Plateau east of the Kharga Oasis, Egypt 5

4. Sketch of flow pattern of slightly negatively bouyant helium bubbles around fluted ventifact from the Western Desert of southwestern Egypt 5

5. Photograph of discarded block of granitic gneiss collected from Chephren quarry in the desert west of Aswan, Egypt 6

6. Photograph of geometeorologic (Geomet) station of the Desert Winds Project undergoing testing and calibration on grounds of U.S. Geological Survey Field Center, Flagstaff, Ariz. 7

7. Photograph of inside of storage compartment for electronic components in Geomet station 8

8. Map showing locations of Geomet stations presently deployed in the deserts of Arizona $\mathbf{1 0}$

9. Photographs of Geomet stations on sites near Vicksburg and Gold Spring, Ariz. 11

10. Chart showing operational history of Geomet station network from late 1979 through late $1983 \quad 13$

11. Maps of surface and upper air conditions over the Western United States that gave $r$ ise to strong wind event of late March 1981 at Gold Spring, Ariz. $\quad 14$

12. Graphs of condensed display of meteorologic data from Gold Spring Geomet station for March 26, $1981 \quad 15$

13. Graphs of condensed display of meteorologic data from Vicksburg Geomet station for August 8, $1981 \quad 16$

14. Erosion-potential semilog chart showing daily precipitation and total daily theoretical capacity of winds to move sand in August 1981 at Vicksburg, Ariz., Geomet site 
Any use of trade names and trademarks in this publication is for descriptive purposes only and does not constitute endorsement by the U.S. Geological Survey. 


\title{
Remote Monitoring of Processes That Shape Desert Surfaces: The Desert Winds Project
}

\author{
By J. F. McCauley, C. S. Breed, P. J. Helm, G. H. Billingsley, D. J. MacKinnon, M. J. Grolier, \\ and C. K. McCauley'
}

\section{Abstract}

Investigations of wind as a geologic agent have been hampered by a scarcity of long-term onsite measurements of wind velocity (including peak gusts, direction, and periodicity), precipitation frequency and intensity, relative humidity, and soil and air temperatures in key desert localities. This report describes a new long-term study, using data obtained by meteorologic and geologic sensors coupled to nonattended solar-powered data-collection platforms. Data obtained from these geometeorologic ("Geomet") stations in type desert areas of Arizona are automatically relayed by the Geostationary Operational Environmental Satellite (GOES) to the U.S. Geological Survey in Flagstaff, Ariz., in real time, and converted to graphic form. Preliminary computer analysis of the data indicates strikingly different meteorologic patterns that control, in great part, the local surficial geology of different desert areas.

\section{INTRODUCTION}

Studies of the conditions that affect the surficial geology of arid and hyperarid parts of the Earth, including parts of the Southwestern United States, have been hampered by an acute absence of data on such key parameters as windspeed and the fraction of time needed above the velocity threshold to erode local surface materials. The short-term time frequency of changes in wind direction near the surface, which also is poorly known, is a key factor in determining the shape and movement of dunes. Also generally unavailable are high-resolution data on the periodicity and intensity of precipitation, as well as on soil temperature, air temperature, and relative humidity. This absence of detailed geometeorologic information is largely due to the inhospitality of desert regions to human habitation, except where groundwater supplies, irrigation projects, oases, or such exotic rivers as the Nile are present. In deserts as a whole, a negative correlation exists between population concentration and areas of high wind, so

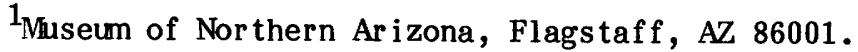

that even today most measurements of meteorologic data in the uninhabited parts of deserts are obtained only during field expeditions of relatively short timespan.

Another problem is that the records at existing isolated stations in deserts commonly reflect the effects of nearby trees and buildings rather than ambient conditions of the surrounding barren areas. Most of these meteorologic stations are located at or near airports for the purpose of supporting local air traffic. Worse, the heights and locations of many of their instruments have been changed during the lifetime of the stations, so that long-term data analysis is difficult, at best. Thus, the role of wind as an agent of erosion, transportation, and deposition in arid regions remains one of the least studied aspects of geology.

The primary source of most present and past meteorologic data in the United States is the U.S. National Oceanic and Atmospheric Administration (NOAA). One of its prime responsibilities is to provide data to the aviation industry and, to a lesser extent, to agricultural interests and the general public. Generalized temperature and precipitation measurements, as well as studies of storm movements and severe weather disturbances, such as tornadoes and hurricanes, are also important interests and responsibilities of NOAA.

The limitations and absence of geologic credibility of the wind data acquired by the U.S. National Weather Service (NWS), a division of NOAA, were summarized by Lyles (1976). Measurements commonly are made at varying heights above the ground, generally at the local airport, and with a wide variety of equipment; thus, the wind data from most stations are not strictly comparable. In addition, most measurements are made with mechanical equipment, and the strip-chart output is laborious to analyze and not readily amenable to computer processing. At most stations, windspeed measurements are averaged over 1-minute intervals once each hour and recorded for submission to the U.S. National Climatic Center (NCC), Asheville, N.C., where they can be retrieved upon request. The NCC can provide yearly summaries of the general meteorology of both U.S. and foreign regions, daily averages for each month at each station, and climatic summaries over the lifetime of a given station; peak-gust data, however, are reported only as the daily extremes. 
As shown by Bagnold (1941), the carrying capacity of wind varies with the cube of the excess velocity of the speed required to set loose particles in motion (threshold velocity), and most of the work of wind is probably accomplished during brief high-energy episodes represented by the peak gusts. Attempts to utilize hourly 1-minute averages for studying wind as a geologic agent (for example, to predict wind power and possible rates of erosion and transportation of surface materials of various grain sizes and cohesiveness) are apt, therefore, to be misleading. In addition, the properties of the boundary layer (the zone of retarded airflow near the ground and below the free-air stream) depend strongly on the degree of surface roughness, which is a function of the surficial geology, topography, and the presence of vegetation of various types. Research on this critically important interface between the atmosphere and the ground surface has been almost entirely neglected except for the empirical work of Bagnold (1941) and the work of the U.S. Department of Agriculture that was spurred by the Dust Bowl catastrophe of the middle 1930's (Chepil, 1956).

Fryberger and Dean (1979) devised a method for converting the windspeed and wind-direction data from World Meteorological Organization (WMO) stations in desert regions into "sand roses," which indicate potential rates of eolian sand transport. Sand roses based on WMO data provide useful syntheses of regional sand-moving wind patterns. They have been used to interpret dune forms, to show directions of sand movement, and to characterize present-day windenergy levels in the world's major deserts (Breed and others, 1979; Fryberger and Dean, 1979). However, the use of sand roses based on WMO wind data as predictors of the actual rates of eolian activity is severely limited by the absence of corollary data on such parameters as actual (as opposed to theoretical) surface roughness, and by the very coarse resolution of the wind data, as described above.

The utility of more frequent and more systematic measurements than those currently available was shown in a study (McCauley and others, 1981) of the 1977 duststorm in the High Plains of the southern United States. This study led to the U.S. Geological Survey's Desert Winds Project to measure key meteorologic parameters by means of remotesensing geometeorological ("Geomet") stations. These measurements, averaged over 6-minute intervals, are transmitted every half-hour to the appropriate Geostationary Operational Environmental Satellite (currently, GOES-6) and back to a receiving station in real time, using a combination of ground and space telemetry, landline transmission, and computer processing (fig. 1). The high-resolution, self-powered Geomet stations are not intended to compete with the various NOAA observation systems; instead, they provide a new data base to study the various meteorologic parameters, particularly those related to wind, that are geologically important in the shaping of various desert environments.

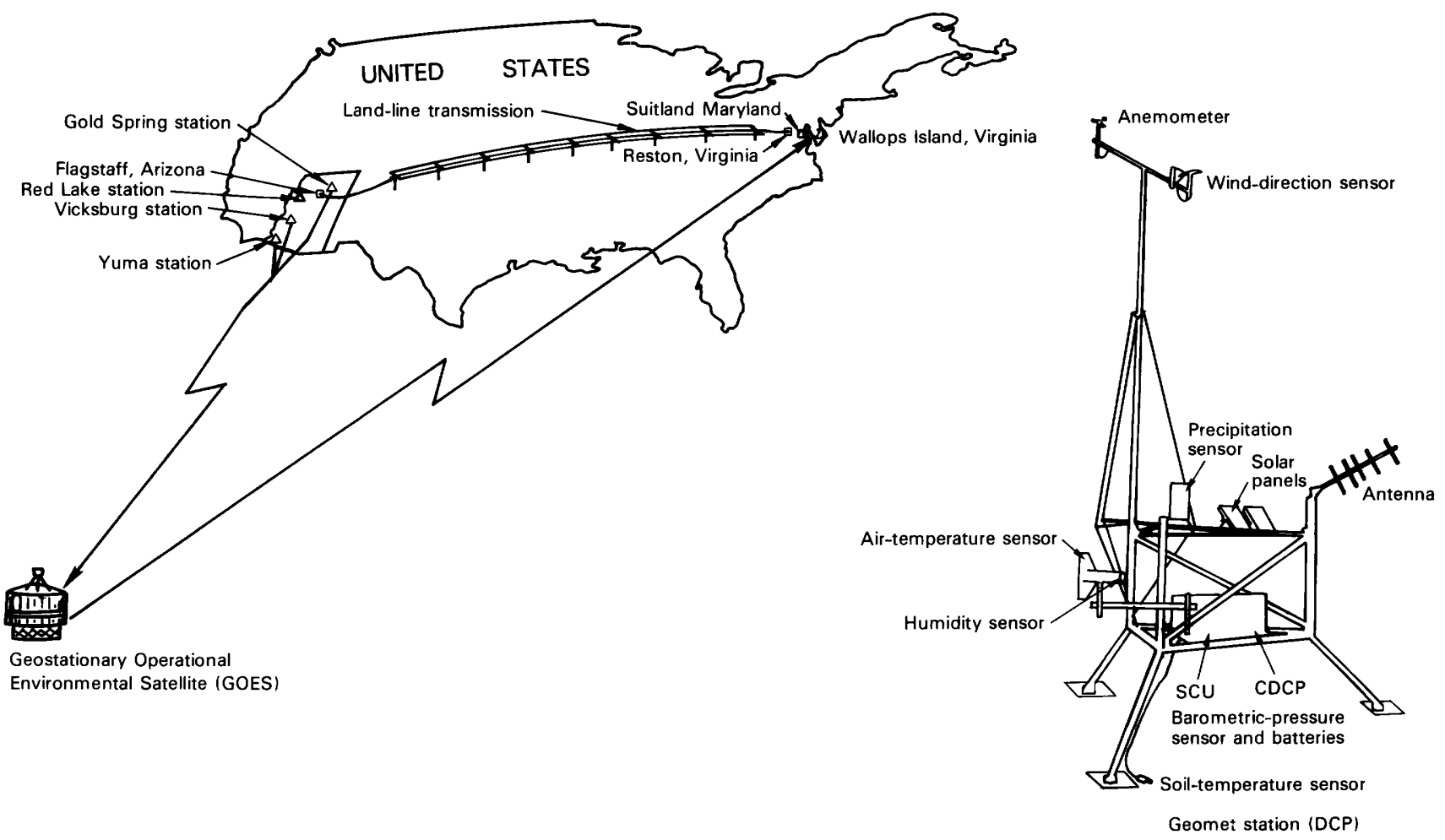

Figure 1. Schematic diagram of data-acquisition and -transmission links for U.S. Geological Survey's Desert Winds Project. GOES, Geostationary Operational

Environmental Satellite; SCU, signal-conditioning unit; CDCP, convertible data-collection platform. See figures 6 and 7 for details of Geomet station. 


\section{Previous work}

Indirect methods used to reconstruct ancient and present wind regimes

One of the first systematic attempts to reconstruct wind directions from the geologic record was by Reiche (1938) in the Coconino Sandstone (Permian) of northern Arizona; this and later work were summarized by McKee $(1979 a, b)$. In these reconstructions, directions of effective (sand-moving) winds in present and ancient sandy deserts were inferred from the directions of dip of slip-face deposits (foreset beds) in sand dunes; these beds form on the lee slopes of active dunes. Changes in wind direction and velocity were inferred from variations in grain size, composition, and sorting, and from crossbeds (sets of steeply dipping laminae truncated and overlain by other sets with a different dip).

Techniques for measuring the dip angles and azimuths of bedding in dune sands require threedimensional cuts to reveal the true dips of the bedding planes. Dip azimuths are then determined in directions normal to leveling lines projected onto the bedding planes of those beds with the steepest dip angles. Azimuths and angles of dip of at least 30 separate bedding sets should be taken in each active or ancient dune area to determine wind-transport directions (Reiche, 1938). Goldsmith (1973) noted that the modal patterns of azimuth distributions are significant, especially where distinct modes correspond to sand-carrying winds from different directions.

The interpretation of wind regimes from dunebedding structures, though widely used in desert studies, has several limitations. First, only winds of sufficient strength to move sand are recorded by the dune beds. Second, winds leave a coherent record only during times when surface moisture, soil temperature, and vegetation density are such that winds can move dune sands in a sustained, orderly way. Third, the times of formation of dune structures cannot be established, and so the intervals between depositional and erosional episodes are unknown. Finally, except for one detailed study (McKee and Douglass, 1971) of the rates of growth and movement of gypsum sand dunes during several intense windstorms at White Sands, N. Mex., the method has not been empirically field tested over extensive periods under varying environmental conditions.

Another method of reconstructing the groundair-interface situation from the geologic record involves analysis of the shapes of ventifacts collected from undisturbed wind-produced surfaces. Ventifacts are found on "pavements" in both desert and nondesert environments in a wide variety of shapes and sizes (figs. 2, 3) that commonly differ from the better known dreikanter (McCauley and others, 1979a). Directions and relative intensities of erosive winds can be ascertained from the patterns of flutes, pits, keels, and undercut surfaces on ventifacts, according to the methods of Whitney (1978), whose earlier work included exhaustive laboratory and field studies of the rates of wind erosion on rocks and minerals of varying hardness and shape.

Wind-tunnel tests (McCauley and others, 1979b) have helped to confirm the reliability of Whitney's methods. Various field-oriented ventifacts were placed in a windblown stream of negatively buoyant helium bubbles, inside the wind tunnel at the Geology Department of the Arizona State University, Tempe. Preferred orientations were determined when the bubbles flowed over, around, and behind the specimens in a manner that conformed to the pattern of flutes and pits on each ventifact (fig. 4). These directions were interpreted to be those of the dominant erosive winds in the areas from which the ventifacts were collected; other orientations for the ventifacts generally gave no correlation between the airflow pattern and the shape or texture of the ventifact.

Ventifact-analysis can yield even more useful wind information where the approximate time of exposure of the rock to shaping by the wind can be established. Examples include wind-eroded implements left by Acheulean and Mousterian occupants of the Western Desert of Egypt during late Pleistocene time (Haynes, 1980), the Libyan Desert glass described by Olsen (1979), and broken blocks of gneiss abandoned at the Chephren quarry of the Fourth Dynasty, dated at about $4,500 \mathrm{yr}$ B.P. (fig. 5), that were observed during our 1979 expedition to the Egyptian Desert. Even when the age of exposure is unknown, analysis of wind-eroded bedrock-surface textures gives useful information about the long-term intensity and direction of erosive winds (McCauley and others, 1977).

Direct methods, using mechanical equipment

The elegant experimental and empirical work of Bagnold (1941), coupled with his extensive field observations, still provides the fundamental basis for much of our current understanding of the work of wind as a geologic agent. By asking such fundamental questions as why sand has the power of selfaccumulation and forms into dunes, whereas dust becomes dispersed, Bagnold was directed toward extensive wind-tunnel work in 1935-36 that led to an improved understanding of the eolian saltation process. He showed convincingly that saltation is essentially a surface process that occurs mostly within a meter or so of the ground and that, except in broken country, sand acts like a "moving carpet," in which the individual grains bounce over the ground. This bouncing motion kicks up more grains and helps to sustain the sandflow downwind from its starting point. The velocity below that necessary to initiate grain movement but sufficient to sustain sandflow for a particular grain size, once flow has begun, was defined by Bagnold as the impact threshold. He also pointed out the relation between surface roughness and the upward-velocity gradient in blowing wind above the surface in determining the sand flow. He defined the fluid threshold velocity $\underline{V}_{t}^{*}$, which is the windspeed necessary to initiate grain movement and saltation. Another important contribution was his discovery that the rate of mass sandflow varies as the cube of the excess velocity above the threshold velocity at which dry sand begins to move.

During the 1970 's, several attempts were made to quantitatively measure wind velocities and directions, precipitation, and other meteorologic data 


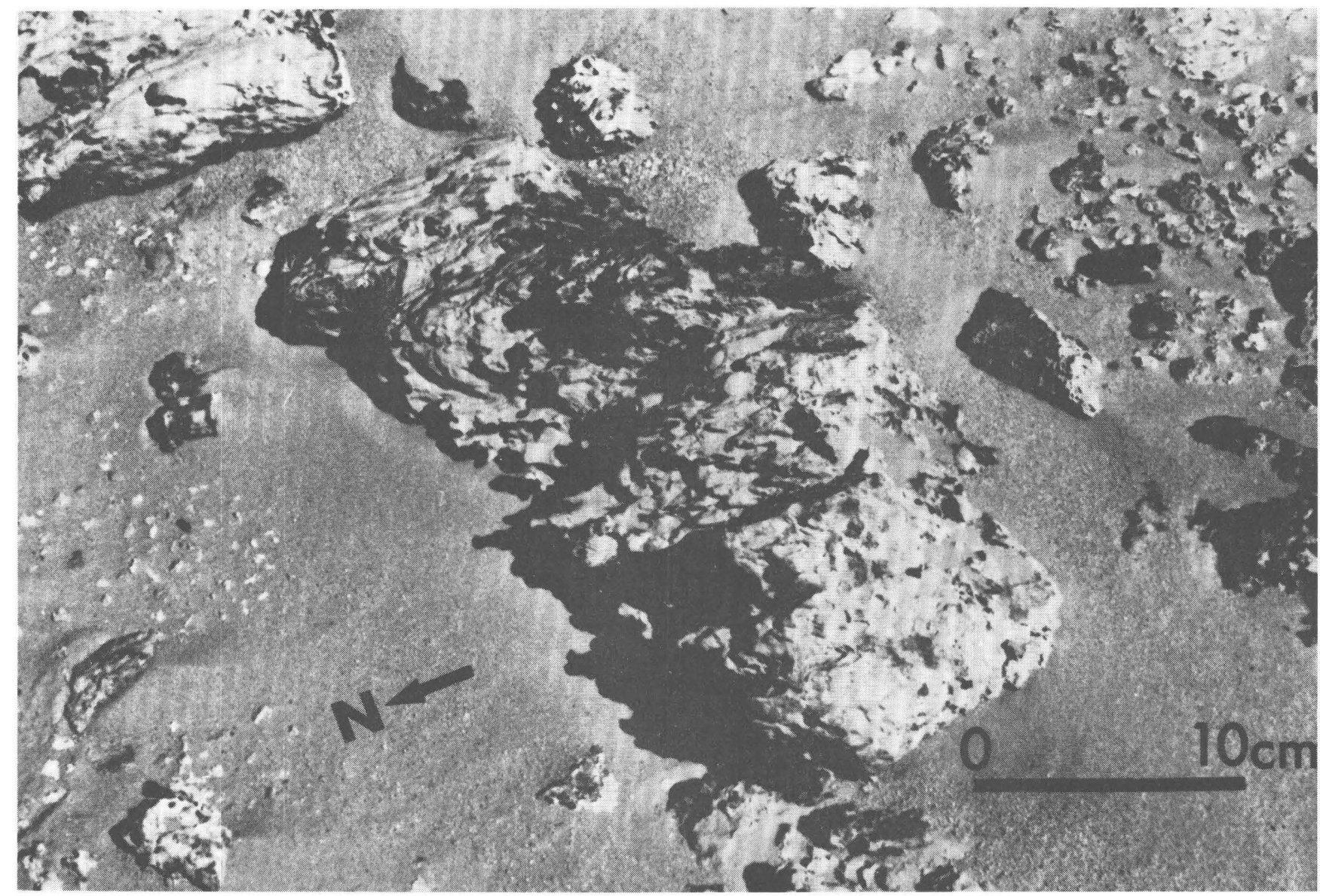

Figure 2. Wind-fluted and corraded "Nubian" orthoquartzite from top of the Gilf Kebir Plateau, southwestern Egypt. Long projections point in direction of strong northerly winds (north arrow on specimen). Precipitation is nearly nonexistent in this desert, which is one of the two most arid regions on the Earth. that may relate to geologic studies of Mars. These efforts were based on machines that produce analog strip-chart output. Late in 1975, we became informally involved in one such study of climbing sand dunes in the western part of the Navajo Indian Reservation, in cooperation with Northern Arizona University, Flagstaff (Cotera and McCauley, 1977). Three portable mechanical weather stations of two types were eventually deployed by C. K. McCauley in various places at the base and top of the climbing-dune field at Paiute Trail Point, about $65 \mathrm{~km}$ northeast of Flagstaff (McCauley and Breed, 1980).

The first machine installed was a five-parameter weather station that records wind velocity and direction, air temperature, relative humidity, and precipitation. These parameters are recorded continuously on the same chart at a speed of $1 \mathrm{~cm} / \mathrm{h}$. The chart motor is powered by a $12-\mathrm{V}$ lantern battery, and the timer uses three 1.5-V D batteries. Each parameter is recorded by a stylus that traces the measurements on pressure-sensitive paper. Although the machine is capable of recording for a total of 90 days, the field records contained numerous gaps due to unpredictable jamming of the chart paper, a failure mode that could not be corrected. Much of this jamming occurred during periods of high windspeed, and thus valuable data on the potential carrying capacity of the wind have been lost.

Later, two other similar machines were installed that record only wind direction and velocity at 2second intervals, and thus allow the recording of shortterm gusts. Two strip charts, one for velocity and the other for direction, are housed in the same case and run by separate motors powered by a $12-\mathrm{V}$ car battery. At a chart speed of $2.5 \mathrm{~cm} / \mathrm{h}$, the machines are capable of recording for a total of 756 hours $(31.5$ days). A pressure bar produces a trace of dots on the pressure-sensitive chart at 2 -second intervals. Wind velocity ranging from 0 to $160 \mathrm{~km} / \mathrm{h}$ is recorded at intervals of $3.2 \mathrm{~km} / \mathrm{h}$. (Input at our stations is currently in customary units but will be converted later to SI.) The windspeed and wind-direction sensor consists of a three-cup anemometer and vane that can be placed at variable heights above the surface.

These instruments required periodic adjustment and repair owing to various component failures in the field. Recorder diodes as well as the brush assembly of the anemometer and vane sensors required occasional replacement. In addition, the anemometer cups broke away from the main assembly several times, and windblown sand occasionally impaired free movement of the sensors or jammed the recording 


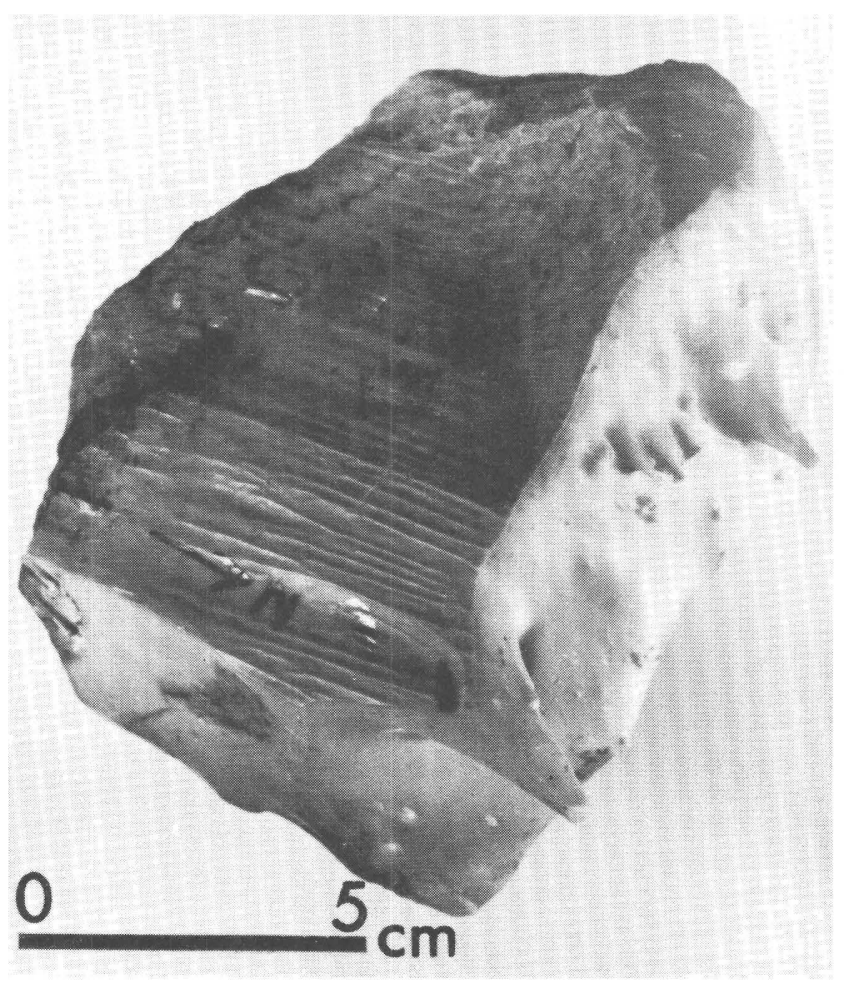

Figure 3. Wind-etched and -fluted ventifact of white crystalline limestone (Thebes Limestone of Eocene age) from the Limestone Plateau east of the Kharga Oasis, Egypt. Windward projections are anchored by small siliceous fossils. Flutes on top surface are eroded by negative flow, which results from boundarylayer separation of airflow, as shown by experimental results (see fig. 4). stylus, although the machines were enclosed in louvered instrument shelters and protected by filters. Frequent failure of the car batteries used as power supplies led to their replacement by larger, longer lived bus batteries. In addition to these repair and maintenance problems, nonsynchronization of the speed and direction sensors made pairing of the data from these machines extremely tedious.

These types of battery-powered strip-chart instruments provide a method of acquiring geologically useful meteorologic data in areas that are reasonably accessible. Because they are subject to various types of mechanical failure, however, they need to be serviced far more frequently than satellite-relay systems. The chief deficiency of these batterypowered instruments is that there is no way to determine when failure occurs. In many cases, failures in the Paiute Trail Point array happened a few days after laborious and expensive servicing, and caused long gaps in the records. In summary, drawbacks to this type of instrumentation for remote geometeorologic monitoring are: (1) the unreliability of many mechanical recording components in a desert environment, (2) the relatively low resolution of the tediously reduced strip-chart data, (3) the need for frequent calibration of the machines-a difficult procedure once they are emplaced in the field-and (4) necessary periodic visits to the machines for replacement of batteries and chart paper.

Despite their drawbacks, these instruments do fill a need and have yielded much valuable information on the complexities of the local wind regime at Paiute Trail Point, particularly on the effects of local topography on the regional windflow pattern (McCauley and Breed, 1980). Machines of this type, however, are only marginally useful for long-term monitoring of conditions in desert regions because technical personnel, vehicles, and time are required to tend the machines properly.

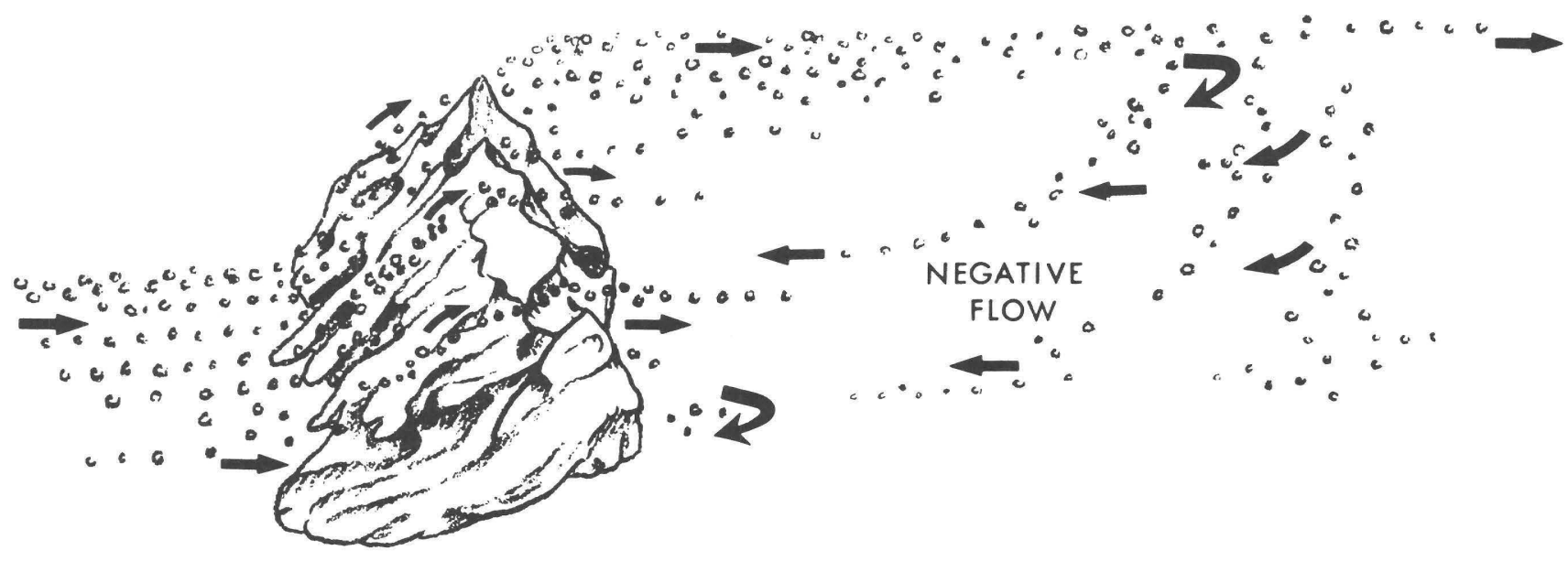

Figure 4. Flow pattern (arrows) of slightly negatively buoyant helium bubbles around fluted ventifact from the Western Desert of southwestern Egypt. Specimen is oriented into simulated dominant wind of that region. Experiment was conducted in wind tunnel at the Arizona State University, Tempe. Note reversal of direction of flow behind ventifact; erosion by this "negative flow" results in carving of pits and flutes on downwind side of specimen. 


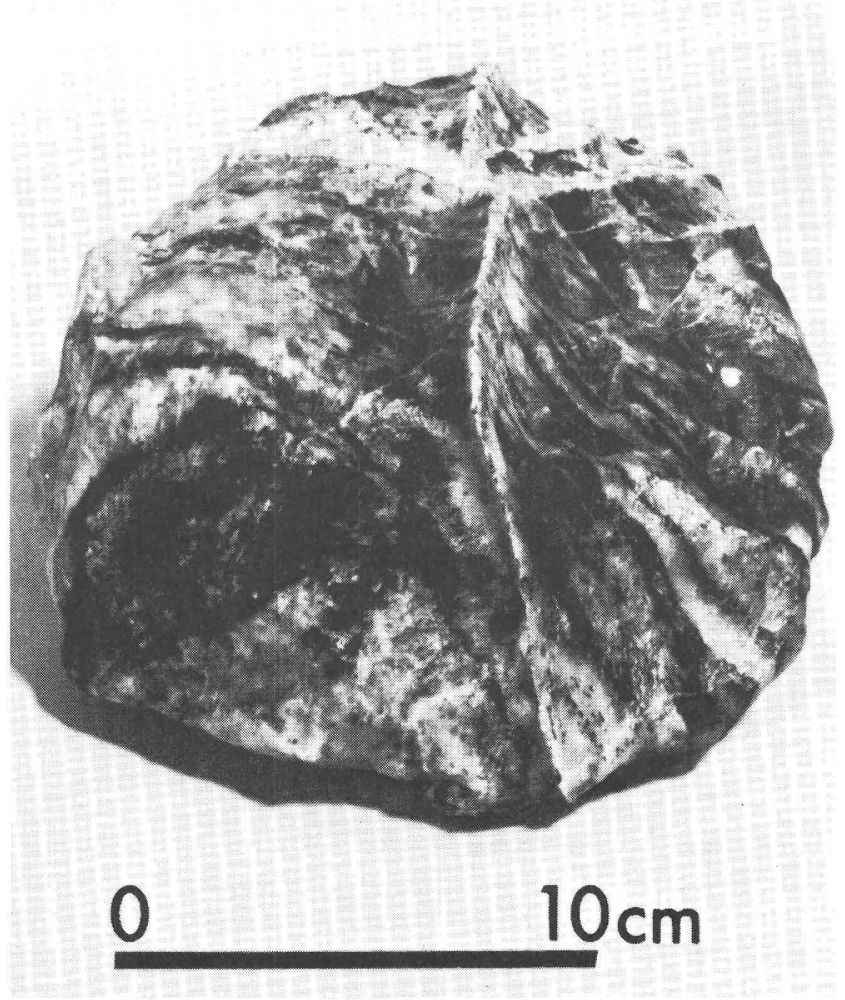

Figure 5. Discarded block of granitic gneiss collected from Chephren quarry in the desert west of Aswan, Egypt. This block, which was probably slabsided when quarried (about 4,500 yr B.P.), now shows extensive wind grooving and raised ribs where resistant quartz veinlets crosscut the gneiss.

Remote monitoring of desert surfaces, using satellite relay systems

During the 1980 's, satellite telemetry provided a major technological breakthrough in the remote monitoring of such meteorologic, hydrologic, and geophysical parameters as wind, temperature, barometric pressure, precipitation, snowpack depth, stream runoff, and seismicity. Remotely located selfpowered stations that can acquire, store, process, and replay at regular intervals both digital and analog data from a wide variety of field sensors are becoming commonplace in the geosciences. These small, portable stations are currently available from several manufacturers and can be tailored to the user's needs. Almost 1,600 such stations are currently in use in the United States, and about 250 are deployed overseas. The largest single user is the U.S. Geological Survey, which has pioneered in their deployment to replace previous labor-intensive methods of monitoring streamflow and other groundand surface-water-related parameters. The work began with a random-access system to the Landsat satellite and was followed by more sophisticated selftimed access systems to geostationary satellites. The U.S. Army Corps of Engineers also has a large array of similar stations for flood-control applications.
The need for better monitoring of climatic conditions in the American West, with emphasis on the role of wind erosion, can be seen dramatically in the recent summary by Sheridan (1981). According to him, 10 percent of U.S. land is undergoing severe desertification, and about twice that area is threatened in those parts of the country that receive less than 20 in. $(50 \mathrm{~cm})$ of annual precipitation. The causes are complex, and the long-term effects difficult to predict, but there is no doubt that each year tens of thousands of acres of cropland and rangeland are being permanently damaged or totally abandoned and left to the ravages of the wind and the growth of undesirable "invader" weeds (Pimentel and others, 1976). Two recent events illustrate the extensive local and regional geologic effects of wind processes on surficial sediments exposed to adverse sets of meteorological conditions.

A significant wind event that caused an enormous amount of erosion within a few hours occurred in the San Joaquin Valley, Calif., during December 1977. The intensity and severity of this storm and its geologic effects were reported by Wilshire and others (1981). Damage included fallen powerlines, blown-out windows and automobile windshields, toppled buildings, extensive sandblasting, defoliation of trees, scouring of bedrock, and deposition of sand in agricultural fields. Telephone poles were sandblasted to their very tops. Particles averaging $2.5 \mathrm{~mm}$ in triaxial dimension were imbedded in poles to heights of $240 \mathrm{~cm}$ above the ground; at $160 \mathrm{~cm}$ above the ground the average size of embedded particles was $3.2 \mathrm{~mm}$, and at $80-\mathrm{cm}$ height the average size was $4.9 \mathrm{~cm}$. Gravel ripples formed in a matter of hours on formerly smooth surfaces. Windspeeds recorded during this event at two weather stations exceeded $150 \mathrm{~km} / \mathrm{h}$; anemometers at two other stations failed at similar windspeeds (Wilshire and others, 1981).

Another devastating event took place during the first winter storm to reach the southern High Plains in the Llano Estacado (Staked Plain) region of western New Mexico and eastern Texas in February 1977. During winter 1976-77, an unusually strong highpressure ridge formed at the surface and also aloft along the west coast of the United States. This persistent ridge pushed the ordinary Pacific storm tracks northward and caused severe winter conditions in the Northeastern States. The high-pressure ridge brought extended drought to the Western States and severely depleted both surface- and ground-water supplies. These conditions set up the southwestern High Plains for one of the greatest duststorms since the Dust Bowl days of the 1930 's; it was, to our knowledge, the first duststorm of this magnitude to be monitored by a geostationary satellite. On February 21, the high-pressure ridge weakened and allowed the penetration of an initially mild storm that rapidly intensified as it moved eastward, and caused northwesterly winds. Two large dust plumes were then observed by the GOES-1-one in eastern Coloradowestern Kansas and another near the Texas-New Mexico State line--at 1700 G.m.t. on February 23. The dust pall from the southern plume spread across the entire State of Texas in about 6 hours; one of its point sources was in the Clovis-Portales area of eastern New 
Mexico. By 2030 G.m.t. on February 24, the pall had been decoupled ffom its source area; it covered at least 1 million $\mathrm{km}^{2}$ and totally obscured, to a height of about $3,000 \mathrm{~m}$, most of the South-Central United States. By 1600 G.m.t. on February 26, a discrete but more diffuse dust pall was still visible as far eastward as the mid-Atlantic Ocean.

The Clovis-Portales area has had a history of aridity and associated high winds from Tertiary time to the present; it has been identified by many authors as the center of the Dust Bowl of the 1930's. We were able to study the ravages of this storm about a week after the event by means of aerial and ground reconnaissance. Erosion of many plowed fields to depths of a meter created myriad small yardangs and blowouts; fine sand was deposited downwind in long lobate sheets that ranged from less than $1 \mathrm{~cm}$ to $1 \mathrm{~m}$ in thickness. A conservative estimate of the total amount of material that was transported in suspension across the Southeastern United States and outward to the Atlantic Ocean is about 1 million $\mathrm{t}$ (Windom and Chamberlain, 1978). The erosion and deposition observed in the Clovis-Portales area probably occurred within about 6 hours. The weather station at Cannon Air Force Base, which is within the area affected, provided detailed meteorologic data (measured at hourly intervals) that greatly expedited our investigation. The above summary is from a more detailed report on this storm (McCauley and others, 1981). This work kindled our interest and showed the need for the experimental array of Geomet stations that is now being deployed.

Acknowledgments.--The Desert Winds Project is supported by the Geologic Framework Program of the U.S. Geological Survey; in its initial phases, this project was also supported by the Survey's Energy Lands and Climate Program. Some of the work in northern Arizona was funded by grants from the NASA Planetary Program in support of projects in eolian studies by the Survey and the Museum of Northern Arizona, Flagstaff. We thank Richard Paulson, William G. Shope, Jr., and Michael Field, all of the U.S. Geological Survey, for their advice in establishing our network of satellite-relay Geomet stations. We also are grateful to Richard MacCallum and Michael Nestlebush of the National Environmental Satellite Data Information Service (NESDIS, formerly NESS), and to Dale Gillette of NOAA, for many helpful discussions.

\section{THE DESERT WINDS PROJECT}

\section{Equipment now being utilized}

Our remote-monitoring satellite telemetry system consists of four major elements: (1) Sensors that measure and detect changes in a given parameter, (2) encoders that convert the output of the sensors to suitable forms for telemetry, (3) a transmission system that provides the link to the GOES, and (4) a datareception and-distribution facility that sorts, decodes, checks, and distributes the data to our laboratory in Flagstaff, Ariz. (fig. 1).

Each Geomet station consists of a convertible data-collection platform (CDCP) and various sensors, all mounted on a three-legged frame (figs. 6, 7). The CDCP is a self-timed system that performs multiple duties: It collects data from the sensors, encodes and converts data into calibrated values, stores data for transmission, and transmits the data to the GOES. At present, each station has identical sensors that measure windspeed, peak gusts, wind direction, air temperature, soil temperature, humidity, barometric pressure, and precipitation.

The windspeed sensor, mounted on a crossarm at the top of a 6.1-m-high mast, is an analog sensor that consists of a three-cup anemometer with a permanent magnet, which operates a sealed magnetic reed switch. Rotation of the cups closes the reed switch

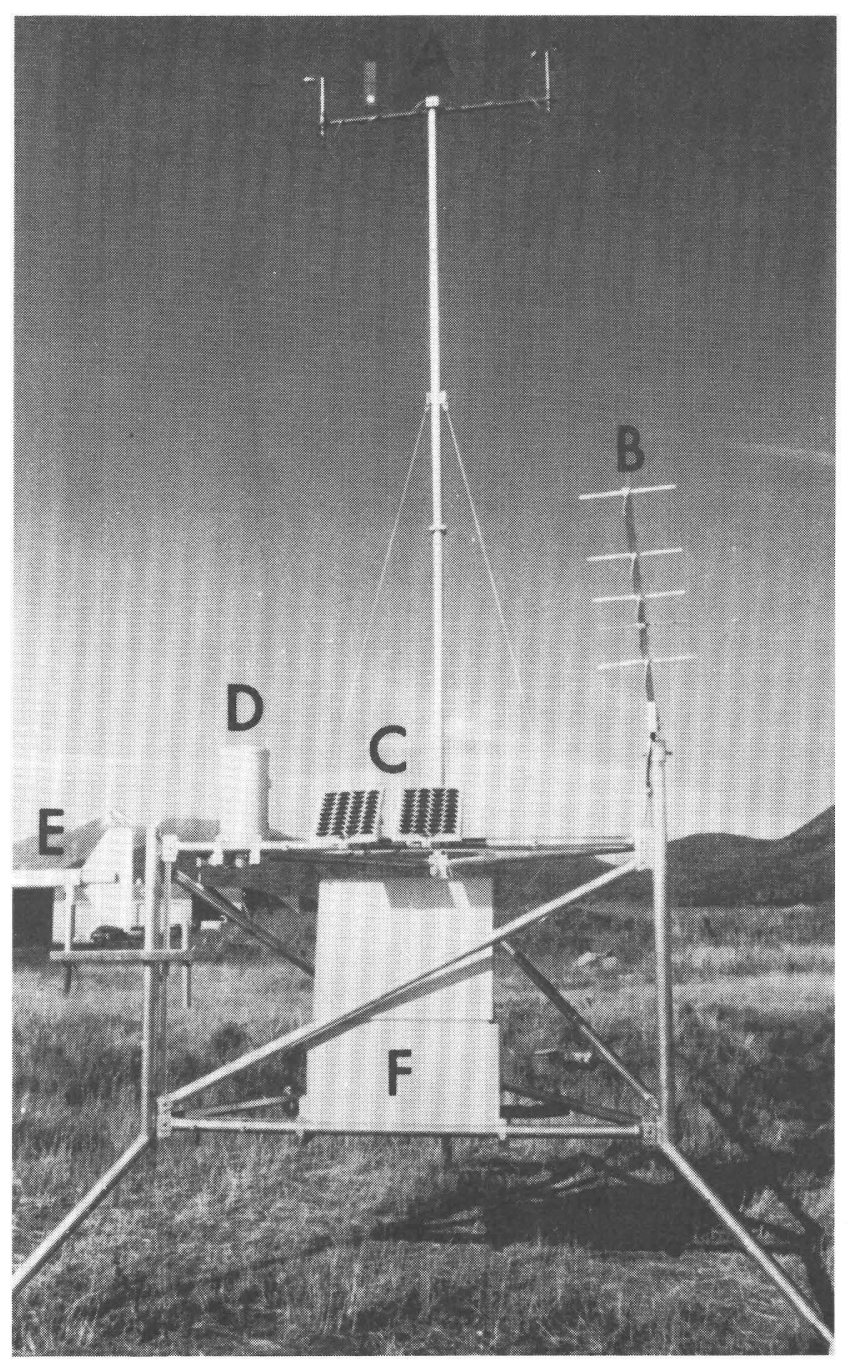

Figure 6. Geometeorologic (Geomet) station of the Desert Winds Project undergoing testing and calibration on grounds of U.S. Geological Survey Field Center, Flagstaff, Ariz. Station is $6 \mathrm{~m}$ high. A, anemometer; B, transmitting antenna; C, solar panels; $D$, precipitation gauge; $E$, radiation shield containing air and relative-humidity sensors; $F$, storage compartment for electronic components (see fig. 7). Soil-temperature sensor is buried in ground nearby. 


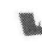
TOP

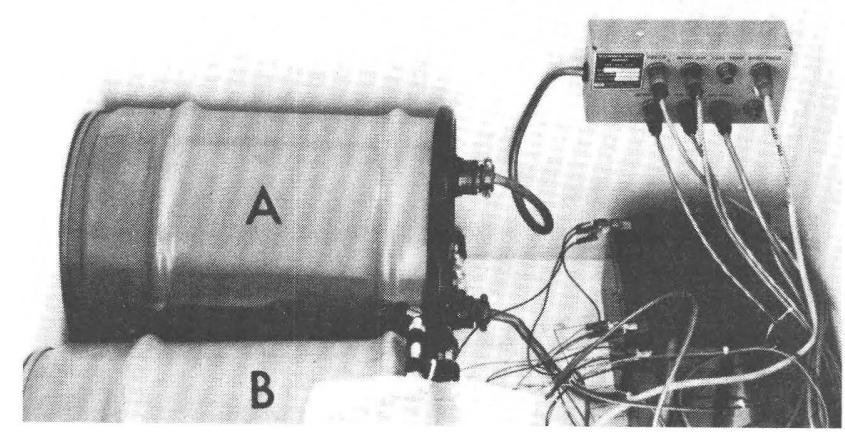

Figure 7. Inside view of storage compartment for electronic components (F, fig. 6) in Geomet station. A, signal-conditioning unit (SCU); $\mathrm{B}$, convertible datacollection platform (CDCP), with clock timer and memory for data storage. Barometric-pressure sensor is also housed in this box.

and provides a frequency of switch closures that is proportional to the windspeed. The data are recorded and converted to an average windspeed calculated over an update interval of 6 minutes; they are then stored for pretimed transmission once every hour. The peak gust within each 6-minute interval is recorded and transmitted at the same hourly intervals.

The wind-direction sensor, also on top of the mast, is an analog sensor consisting of an airfoil metal vane. The vane is coupled to a wire-wound potentiometer whose output voltage varies proportionally with the wind direction. The sensor is powered continuously, and an average wind direction is calculated over the 6-minute update interval.

The air-temperature sensor is an analog sensor consisting of a solid-state linear three-element thermistor. The output of the sensor is a resistance proportional to the ambient temperature. The sensor is protected by a solar-radiation shield and is mounted $1.5 \mathrm{~m}$ above the ground.

The analog soil-temperature sensor is similar to the air-temperature sensor. The thermistor, contained in a metal dowel, is buried to a depth of $127 \mathrm{~mm}$.

The analog relative-humidity sensor is a polymer thin-film capacitor. The capacitor is composed of an upper and lower electrode with an organic polymer dielectric about $1 \mathrm{~m}$ thick. Water vapor is absorbed into the polymer, and the capacitance changes linearly as the moisture increases or decreases. The sensor is contained in the radiation shield along with the airtemperature sensor.
The analog barometric-pressure sensor consists of an evacuated bellows that is sensitive to changes in absolute pressure. The measured resistance is proportional to the barometric pressure.

The digital precipitation sensor consists of a funnel, $20 \mathrm{~cm}$ in diameter, that collects water and delivers it to a twin tipping-bucket mechanism. Each time $0.2 \mathrm{~mm}$ of precipitation has been collected, the bucket tips and causes a mercury switch to close momentarily. The sensor is powered continuously to generate a count of switch closures during the update interval.

Each sensor interfaces with the microprocessor of the CDCP by means of an input/output signalconditioning unit (SCU). Inside the SCU are signalconditioning cards that correspond to each sensor. The output from all the analog sensors is encoded to a 0 - to $5-\mathrm{V}$ scale, and these analog voltages are sent to the microprocessor with the digital count from the precipitation sensor. The microprocessor, in turn, sends a signal through the SCU to the sensors every 6 minutes to power those sensors not continuously powered and to record the information collected by each sensor. The power supply for the station includes a $12-\mathrm{V}$ battery and two solar panels that recharge the battery continuously during sunlight hours. Various types of batteries have been used; no one type is presently preferred.

Both the SCU and the microprocessor of the CDCP, which controls the activity of the entire platform, are housed in a metal box (fig. 7). A clock timer and the memory for data storage are also part of the CDCP. When the output from the sensors arrives (every 6 minutes) from the SCU, the microprocessor converts each reading into a "hexadecimal" number that is then stored in the memory. Each station has been assigned by the U.S. National Environmental Satellite Data Information Service (NESDIS) a 1minute window for transmission of data, and the clock timer in the CDCP is programmed to control transmission at the preassigned time. The ten 6-minute updates are transmitted in "hexadecimal" format every hour.

The GOES-6 that we are currently using is in circular orbit $36,000 \mathrm{~km}$ directly above the Equator, and so the speed of the spacecraft on its orbital path matches that of the Earth's rotation. This satellite is at long $135^{\circ} \mathrm{W}$. and is available for stations in the Western United States. The small antennas on our stations are alined to transmit to this satellite, which receives the data on a preassigned channel and retransmits it to a central receiving station at Wallops Island, Va. From there, the data are sent by landline to Suitland, Md., sorted into user files, and retrieved by users with high-speed dedicated or low-speed dialup lines (fig. 1). The dialup low-speed (300 baud) teletype terminal also allows for instant access to the coded data for transmission or checking of time-slot errors.

Software has been developed for extracting data from the user queue and for analyzing the data by way of a dialup line from the VAX-750 computer in Flagstaff, Ariz., to the NESDIS computer. The data are stored on disk in the computer for 1 month and then are written onto a tape that is stored in the U.S. Geological Survey tape library in Flagstaff, Ariz., and is available for future use. 
Special sensors and additional station-related experiments

The amount of dust passing through or originating from the area under surveillance is particularly significant. Because airborne dust particles smaller than $25 \mathrm{~m}$ in diameter move at the same speed and in the same direction as the wind, measurement of dust concentration and windspeed at a single point will provide a measure of the local dust flux (the rate at which dust is passing through a unit area perpendicular to the wind direction at the point of measurement). These measurements, however, do not indicate whether the material being measured is being eroded from local sources, is passing through, or is being deposited. A commercially available dustparticle counter, which actually counts the number of dust particles larger than a certain diameter that pass through a calibrated light beam, has been automated to make measurements that are transmitted simultaneously with other data from the Geomet stations. One of these experimental dust-flux sensors was deployed in early 1984. For reasons related to data capacity, only two size ranges were chosen for measurement: diameters of at least $0.5 \mathrm{~m}$, and diameters of at least $5.0 \mathrm{~m}$. If this device works successfully in the field, we will fit all our stations with similar devices. This application will be a pioneering effort in the adaptation of these units to remote low-powered stations.

Sand-cloud properties are not so easily determined, primarily because the individual grains do not travel at the same speed and in the same direction as the wind. Moreover, even a sand cloud having grains of uniform size consists, at any one point, of grains moving with widely varying speeds both vertically and horizontally. Sand-flux measurements require knowledge of both the speed and mass (or size) of the sand grain. (The product of these two parameters is the particle momentum.) At present, there does not appear to be a simple, cost-effective method to measure, uniquely and independently, both parameters, either individually or collectively, in naturally occurring sand clouds. Dale Gillette of NOAA is attempting experiments with piezoelectric crystals configured to determine sand-flux properties. The crystals respond, upon particle impact, with an electrical pulse that is proportional to the sand particle's momentum. It remains to be seen whether differences can be distinguished between a slow-moving large particle and a fast-moving small particle, and whether coincident collisions significantly alter the momentum information that is contained in the crystals' electrical output.

The sand-flux sensor that we have recently deployed (along with the dust-flux sensor) at one of our stations is a modification of the type designed by Fryberger and others (1979). We have modified the sensor, for this project, by replacing the eight directionally divided storage bins with a tipping-bucket device similar to the precipitation sensor already in use. The amount of sand collected per unit time can then be directly related to specific meteorologic conditions. The directions from which the sand is collected, and the windspeeds, can be inferred from the wind-direction and-speed sensors on the Geomet stations.

Other experiments involve data that are not digitized and relayed to the GOES; these data must be manually retrieved at irregular intervals. An example is the panoramic photographic coverage of different types of surfaces around each station. These photographs provide visual evidence of changes in surface geologic and topographic features and vegetation over time. In addition, at various heights on the frames of two of our stations, we have attached arrays of "virgin" quartz grains of various sizes mounted on aluminum plates. These grains, made from Brazilian quartz crystals, have been episodically removed and replaced for study of abrasion and possible solution effects, by use of the scanning electron microscope. Preliminary results (Krinsley and others, 1981) indicate substantial abrasion of the grains mounted at our Vicksburg, Ariz., station, probably as a result of the severe windstorms that struck the area in July and August 1981 (see discussion below).

\section{SITE SELECTION AND ASSOCIATED GEOLOGIC STUDIES}

The five Geomet stations ultimately planned for our array will be deployed to identify the greatest possible variance among the different types of deserts that exist in Arizona (fig. 8). Four stations are already operational: in the extremely arid lower Sonoran desert near Yuma (on a U.S. Marine Corps base), in the higher Sonoran desert at Vicksburg (fig. 9A), in the Great Basin Desert on the Navajo Indian Reservation at Gold Spring (fig. 9b), and in the easternmost Mojave Desert at Red Lake. A projected fifth site is in the Wilcox playa area of southeastern Arizona close to the northwest edge of the Chihuahuan Desert, which lies mostly in Mexico. Each of these deserts is known to have seasonally distinctive wind and rainfall patterns as well as distinctive geology, flora, and fauna. For example, the Mojave Desert is characterized by widespread winter rains, and the Sonoran Desert by sporadic, unevenly distributed summer cloudbursts.

Within each of these areas, considerable time and care were expended to find a site that was representative of each desert type as a whole, where maximum security from possible vandalism could be obtained. To put the sites into context, detailed geologic field studies in the immediate vicinity of each machine, and a general synopsis of the regional geology, have been done or are planned.

The preliminary geologic study of the Vicksburg site (fig. 9A) that follows exemplifies the type of geologic background needed to gain maximum benefit from the the quantitative meteorologic information generated by each machine.

\section{Vicksburg site}

A site southwest of Vicksburg on the Ranegras Plain, about $100 \mathrm{mi}$ west of Phoenix, was chosen for studying the effects of wind and water erosion in the Gila Desert (figs. 8, 9A). The Ranegras Plain is a 


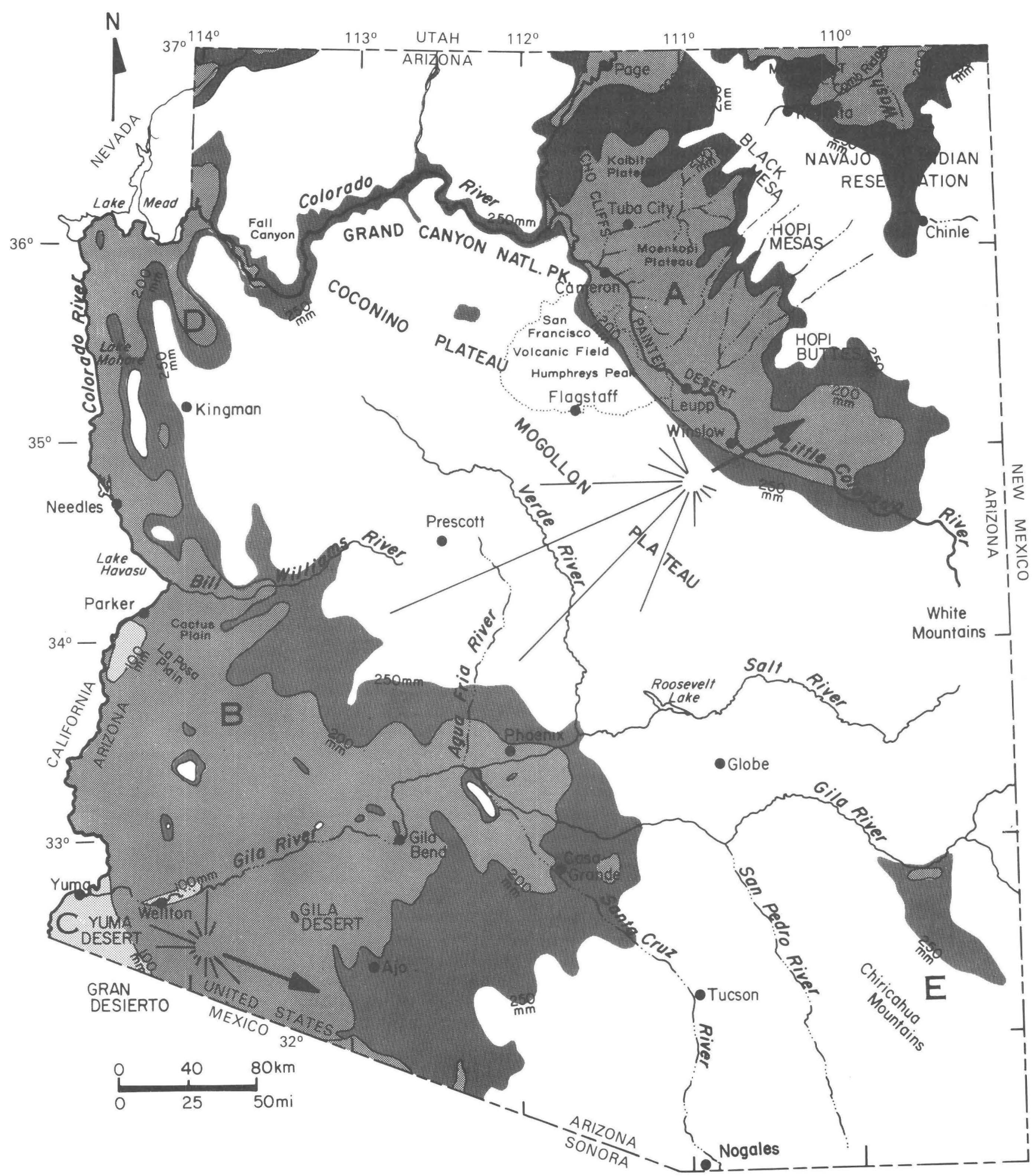

Figure 8. Locations of Geomet stations presently deployed in the deserts of Arizona. A, Gold Spring; B, Vicksburg; C, Yuma; D, Red Lake; E, station yet to be deployed at Wilcox Playa. These sites represent all five of the major desert environments in Arizona. Darkest areas receive the least precipitation, and white areas the most, as shown by precipitation isohyets (in millimeters per year). Annual sand roses (Fryberger and Dean, 1979) show directions of potential sand-moving winds; length of sand-rose arms is proportional to frequency of occurrence of winds faster than about $25 \mathrm{~km} / \mathrm{h}$ from each compass direction. Arrows show calculated resultant direction of potential sand drift. Sand roses are based on analysis of monthly summaries of wind measurements from U.S. National Weather Service weather stations at Yuma and Winslow, Ariz. Modified from Breed and others (1984). 

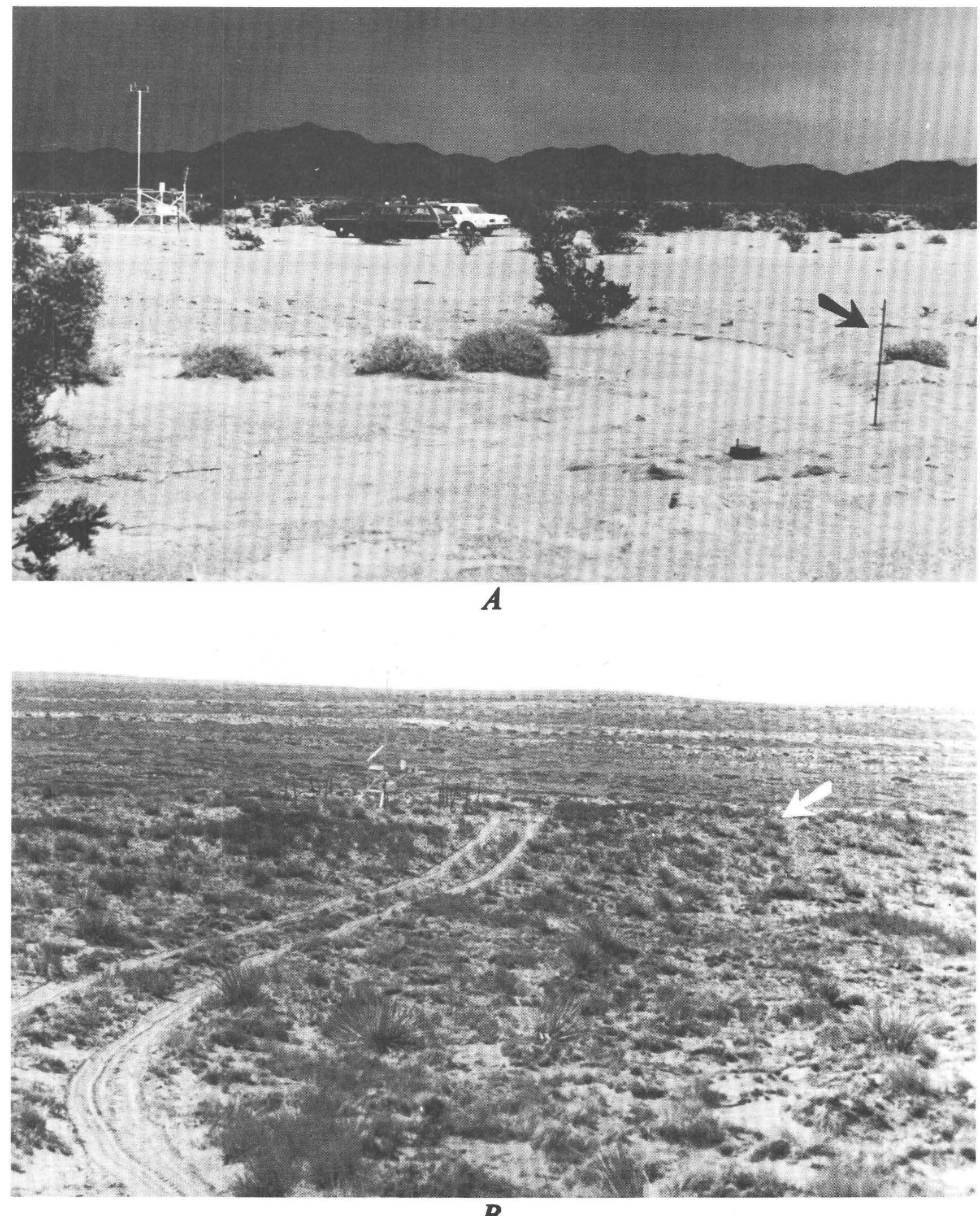

Figure 9. Geomet stations on sites near Vicksburg (A) and Gold Spring (B), Ariz. Sites differ in geographic setting (intermontane basin in fig. $9 \mathrm{~A}$, high plateau in fig. 9ㅁ), vegetation, surface geology, and types of

storms (see figs. 12, 13). Arrows denote location rods for photographic monitoring of surficial changes at sites. 
broad desert valley that surrounds Bouse Wash in northeastern Yuma County; it has a hot and arid climate and very little vegetation. The Geomet station is near a small dune field in the NE1/4SW1/4 sec. 9, T. 4 N., R. $15 \mathrm{~W}$. Topographic relief within a half-mile of the station is less than $3 \mathrm{~m}$.

\section{Subsurface geology}

Although the subsurface geology of the Vicksburg site is little known, the known subsurface geology to the west and north near Bouse and Parker (Metzger and others, 1973) may extend throughout the subsurface of the Ranegras Plain. The deepest known sediment near Bouse and Parker is a pebble fanglomerate, possibly 300 to $400 \mathrm{~m}$ thick, whose composition resembles that of present-day alluvial fans. Beds in this basal fanglomerate generally dip from the mountains toward the basin and vary widely in thickness. The fanglomerate may be Pliocene in part; the overlying Bouse Formation has not been dated precisely. A possible maximum age, middle Miocene(?), can be inferred by correlating the fanglomerate with a similar unit west of Needles, Calif., that contains a fossil-vertebrate fauna.

A sharp unconformity between the fanglomerate and the overlying Bouse Formation represents a change in environment from land-laid deposits to those deposited in an extension of the Gulf of California. The Bouse Formation is a marine to brackish-water sequence composed of a basal limestone overlain by interbedded clay, silt, and sand. Several marine fossils were found in the Bouse Formation but are not diagnostic for age dating. The age of the Bouse can be established broadly as Pliocene on the basis of ages obtained from a thin overlying tuff (Metzger and others, 1973). The Bouse Formation is exposed about $20 \mathrm{~km}$ northwest of the Vicksburg site, near Bouse, Ariz., where it exceeds $60 \mathrm{~m}$ in thickness; it probably also underlies the Ranegras Plain in the Vicksburg area.

Metzger and others (1973, p. G16) reported that $" * *$ * some of the well-cuttings in the Bouse contain small pebbles, for the most part enclosed by clay. Because the pebbles are 'floating' in the clay, it is inferred that they were probably dropped into the body of water from rafts of vegetation." This relation may be explained in another way by analogy to recent deposits near Vicksburg, where pebbles and gravel are presently accumulating in the clay playas. The pebbles are washed in by occasional flash floods of low velocity and high density. As the silt-laden floodwaters evaporate on the playas, the scattered pebbles and granular material are encased in clay.

The Bouse Formation is easily eroded by stream action, and part of the Bouse was removed before deposition of about 40 to $300 \mathrm{~m}$ of recent alluvium. Several episodes of fluvial degradation and aggradation have occurred since deposition of the Bouse.

\section{Surficial geology}

Present-day drainage in Bouse Wash is ephemeral. The entire flood plain is inundated by slow-moving floods in wet intervals, which occur only a few times over a period of several years. The Ranegras Plain slopes less than $1^{\circ} \mathrm{NW}$. and is cut by braided and manmade channels that are generally less than $1 \mathrm{~m}$ deep. The sediment in the channels consists largely of coarse sand. Clay or silt veneered with purple pea-size gravel and pebbles covers 90 percent of the plain. A few sparse low (0.3-3 $\mathrm{m}$ high) perennial creosote bushes and some larger (1.5-2 $\mathrm{m}$ high) mesquite and creosote trees and bushes are scattered along erosional channels.

The Ranegras Plain may have had no external drainage during much of Pleistocene and Holocene time because drainage was cut off by aggressive alluvial-fan encroachment from the mountains on both sides of the valley. Playas were probably intermittent and small throughout the valley. The playa deposits consist of clay and sand, interbedded with alluvial-fan and stream deposits along the valley margins. In periods of dryer than normal conditions, windblown clay, silt, sand, and gravel gradually accumulated on the east edges of the playas.

The small dune field near the Geomet site is not easily recognizable. The dunes are partly vegetated and form a series of parallel linear ridges trending north-south. The ridges have gentle slopes on their east and west sides. Dune elevations change gently in the direction of ridge elongation; the greatest relief is near the dune centers and decreases toward their extremities. No internal bedding structures were visible in the dunes where small trenches were dug, although horizontal and very low angle bedding does occur in the uppermost few inches of the dunes at some localities. In several places, runoff from the surrounding alluvial fans appears to have cut through the larger sections of the dunes. Apparently the ephemeral-drainage gullies predate the dunes, which have established themselves across them and effectively blocked the smaller streamcourses, though not the persistent and larger ones. This interpretation implies that the dunes postdate the alluvial-fan drainage systems and, possibly, the Bouse Wash playas as well. The dunes have been extensively disturbed by various burrowing animals, notably the coyotes, rabbits, and mice who make their homes in the dune field.

The dune-sand deposits are very poorly sorted; grain size ranges from granules $(3.33 \mathrm{~mm})$ to clay particles $(<0.0020 \mathrm{~mm})$. Skewness records excessive fines, and kurtosis is platykurtic. The average median grain size (based on four sieved samples) is $0.28 \mathrm{~mm}$ (1.87 $)$, a medium sand. The corresponding threshold velocity $\mathrm{V}_{\mathrm{t}}$ at the $6.1-\mathrm{m}$ elevation of the wind sensor (calculated from the equations of Bagnold, 1941) is 8.5 $\mathrm{m} / \mathrm{s}$. Grains of nearly all sizes are angular to subangular; several crystalline grains are composed of quartz, feldspar, and biotite. Dark minerals average 16 percent of the dune grains, and light minerals 84 percent. These characteristics imply a short time and distance of transport from the sources of these materials. The composition of the dune sediment indicates that the main source is the Little Harquahala and Granite Wash Mountains, about $10 \mathrm{~km}$ to the east; a minor source is the Plomosa and New Water Mountains, about 10 to $20 \mathrm{~km}$ to the west. 
Surface geologic processes

Ephemeral drainage on the present-day alluvial fan intersects the dune ridges perpendicularly from the east. Runoff along the gullies forms small playas before it is diverted around and between the dunes. Moderate to large amounts of eolian sand are observed in transport, as well as much eolian dust derived from the nearby barren alluvial plain of Bouse Wash. It is uncertain at this time whether the local dune field was formed by prevailing southwesterly and westerly winds or by opposing strong winds from the northwest and southeast; data from the Geomet station should help answer this question. The intermittent deposition of sand along the shores of the playas by water waves also may be an important factor in the formation of these dunes.

Deposition of all the surficial units at the Vicksburg site reflects an interplay of wind with running and standing water. Surrounding the dunes and bordering the local playas is a mantle of alluvial deposits veneered by gravel. A desert pavement armors undisturbed surfaces of the alluvial deposits against deflation. Mud cracks and mud curls are common on the playa areas, which are a major source of windblown dust particles. Sand sheets and small sandpiles accumulate at the edges of the playas near the terminal ends of many alluvial-fan drainage gullies; eolian reworking of these deposits, in turn, begins to form small elongate dunes. A local environment of rapidly fluctuating water and wind currents, from almost slack to violently energetic activity, is reflected in the poor sorting of the dune material.
For each desert area, we intend to use our meteorologic data, in combination with the type of background geologic information outlined in the preceding section, to determine the efficiency of wind as a geologic agent and to assess the importance of other parameters in the overall erosional and depositional regime. The Vicksburg area is one of many source areas that give rise to intense duststorms that severely curtail visibility and hamper road traffic in the Phoenix area. Therefore, our long-term detailed studies ultimately should have practical value in determining the approximate frequency of occurrence of such events and the particular combination of geologic and meteorologic conditions that favor their occurrence.

\section{DATA ANALYSIS AND DISPLAY}

Methods are under study for systematic display and analysis of the data received from the four Geomet stations presently operational. We now have more than 3 years' data from our Gold Spring station. The stations near Vicksburg, near Yuma, and at Red Lake have been plagued with intermittent major and minor problems, the most serious of which has been drifting of the transmission frequency used to communicate with the GOES. Figure 10 summarizes the operational history of the stations and indicates the types of problems that cause gaps in the data. We believe that most of the technical problems have now been corrected and that ensuing records will be more continuous. Two examples of the records from recent separate wind events at Gold Spring and at Vicksburg are described below.

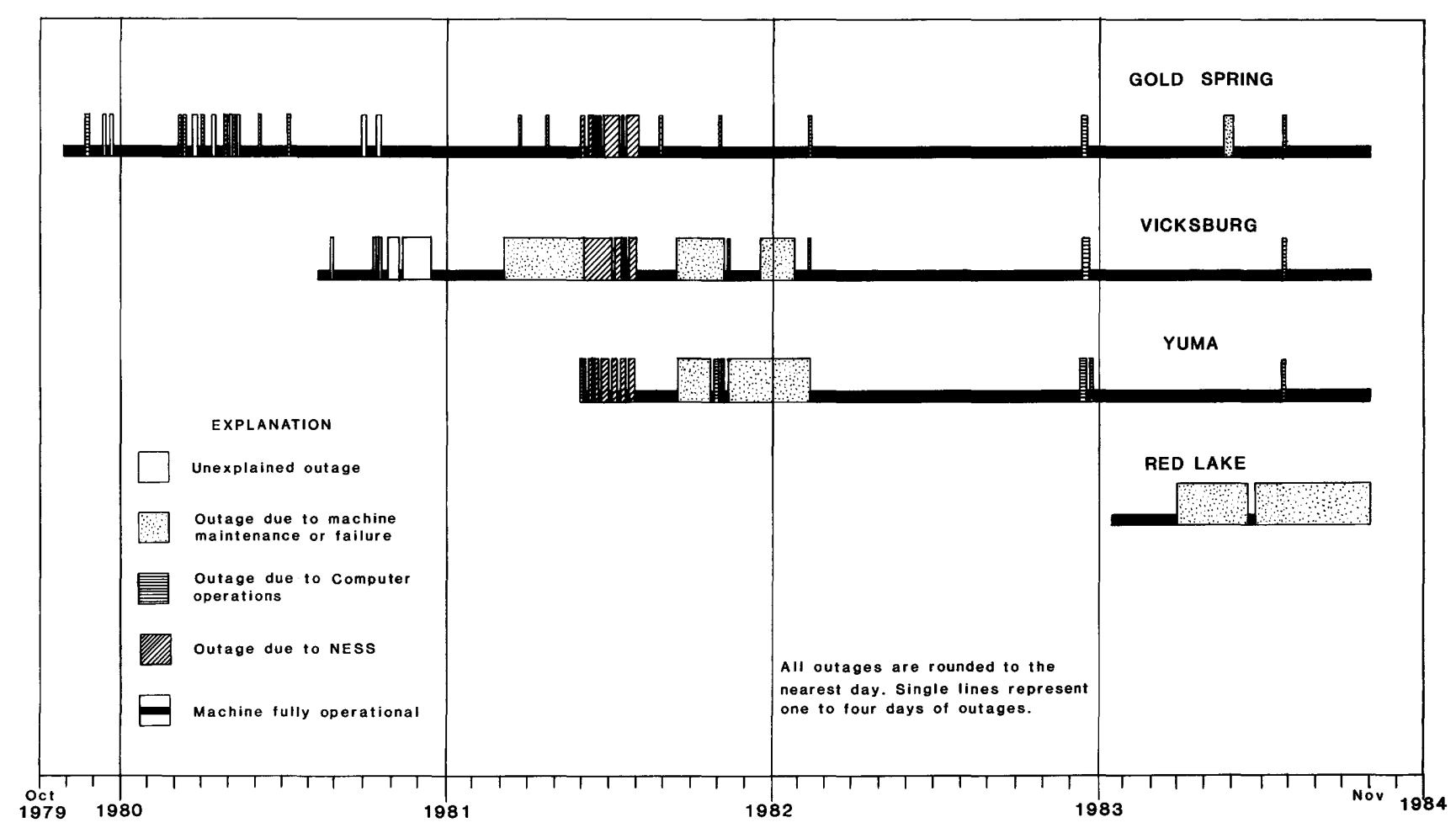

Figure 10. Operational history of Geomet station network from late 1979 through late 1983. 
Gold Spring, Ariz., event

On March 25, 1981, an intense surface and upperlevel low-pressure center developed and dropped southward toward the Intermountain States (fig. 11). Data from the Gold Spring station (fig. 9b) showed moderate winds from the south-southwest. By the morning of March 26, the surface and upper-level lows were in an ideal position to cause strong winds in northern Arizona. Although the surface winds that morning were relatively light at Gold Spring, the winds aloft were extremely strong. In northern Arizona, few clouds were associated with this storm, and solar heating of the surface allowed turbulent interchange between the surface and upper air layers. The result was an explosive increase in winds after 1000 local standard time (l.s.t.). By the evening of March 26, the winds returned to moderate speeds and remained so throughout the next day. This type of event can cause severe sandstorms and duststorms if the ground surface is dry and a sufficient amount of loose clay- to sand-size material is available.

Figure 12 plots the measurements obtained at Gold Spring on March 26. Wind intensity shows a symmetrical pattern, with a broad peak lasting from 1100 to 1800 l.s.t. and a wide spread between peak gusts and the average wind velocity. During the period of highest peak winds, the wind direction was steady from about azimuth $260^{\circ}$ (west-southwest). The peak of the windstorm coincided with a low in the relativehumidity curve, which also coincided with diurnal heating or the influx of dryer air. The period when the air and soil temperatures were equal, between about 1330 and 1530 l.s.t., approximates the midpoint of the wind event; when the soil temperature exceeded the air temperature, the wind intensity was either increasing or decreasing. The calculated threshold velocity at Gold Spring, where the average grain size of the surface sand sheet is $0.135 \mathrm{~mm}(2.90)$, a fine sand, is about $13 \mathrm{mph}(5.8 \mathrm{~m} / \mathrm{s}$, at the $6.1-\mathrm{m}$ elevation of the windspeed sensor) according to Bagnold's (1941) equations; therefore, winds during this event were competent to move these surface sands under ideal conditions. We do not know, however, what sizes or amounts of sand actually moved, in the absence of flux sensors at the time of the event.

\section{Vicksburg, Ariz., event}

Several diverse but locally intense windstorms struck in the vicinity of our Vicksburg station in July 1981. Figure 13 plots the data from one of these events. G. H. Billingsley visited the area on August 6 , shortly after the storms had passed through, and provided the following report.

My first stop was the house of Tom Lowe custodian of the Vicksburg station, where I took pictures of the wind damage that occurred during a storm on July 10,1981 . Only the four outside walls of the wooden-frame house were still standing; the roof, porch, windows, and doors were missing. Trees nearby were broken and shredded; some outbuildings were leaning over and badly damaged but not yet flattened. Parts
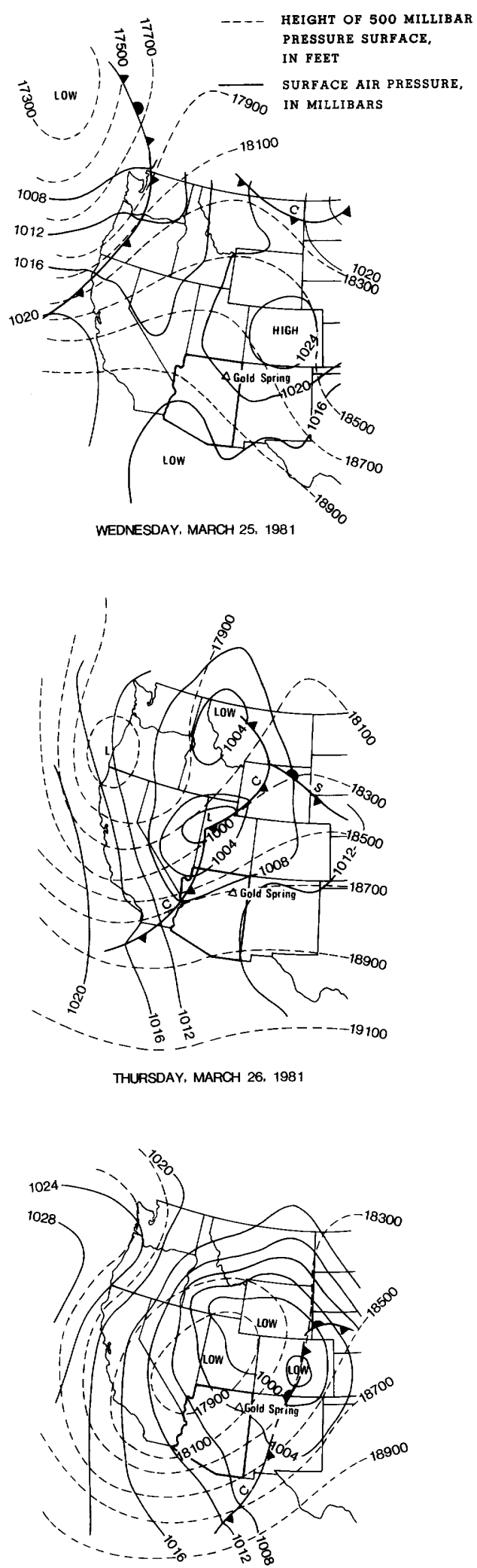

FRIDAY, MARCH 27, 1981

Figure 11. Surface and upper-air conditions over the Western United States that gave rise to strong wind event of late March 1981 at Gold Spring, Ariz. C, cold front; $S$, stationary front; $O$, occluded front. 


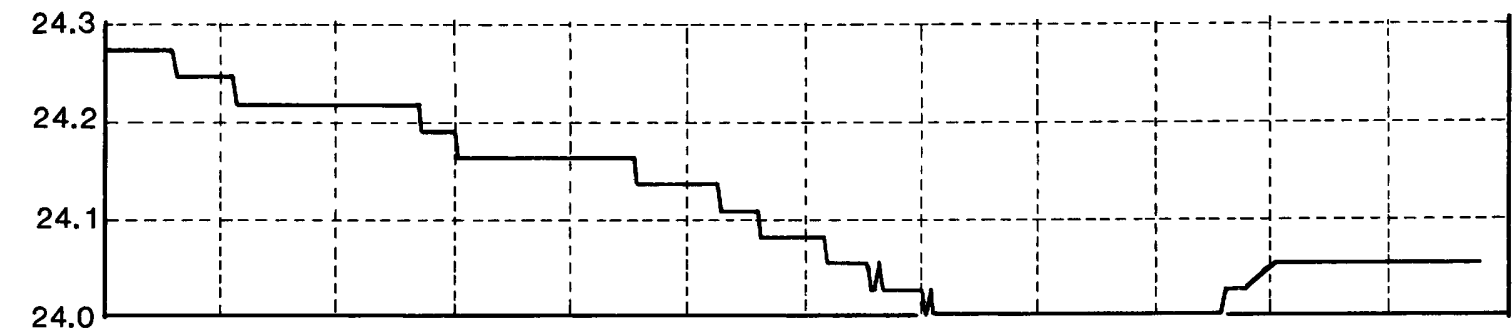

\section{四}
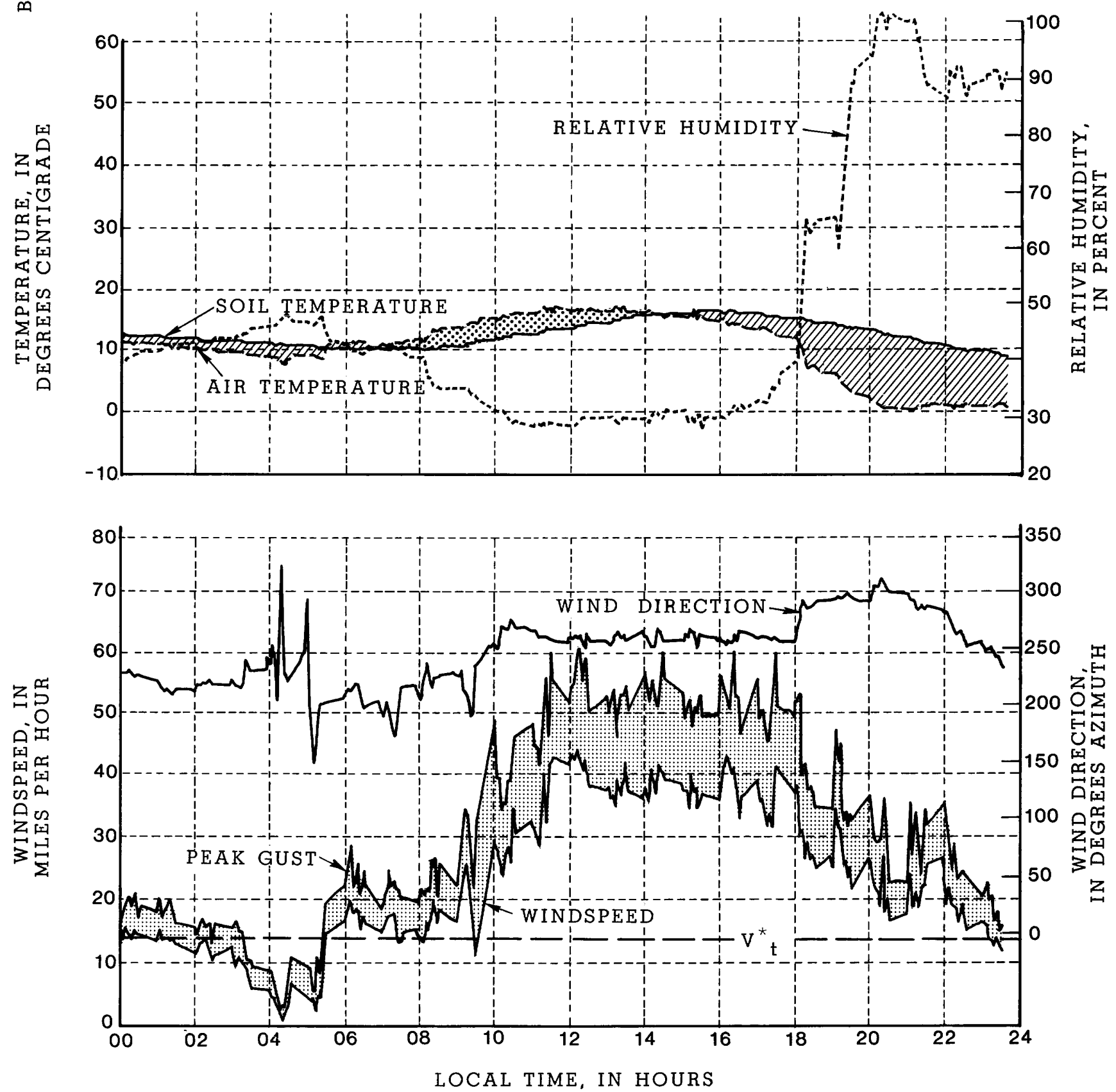

Figure 12. Condensed display of meteorologic data from Gold Spring Geomet station for March 26, 1981. During a period of 16 hours, windspeeds averaged over 6-minute intervals and peak gusts greatly exceeded fluid threshold velocity $\underline{v}_{t}^{*}$ (Bagnold, 1941) for eolian sand transport; $V_{t}^{*}$ for average-size surface sand in this area is approximately $5.8 \mathrm{~m} / \mathrm{s}$ (heavy dashed line). 

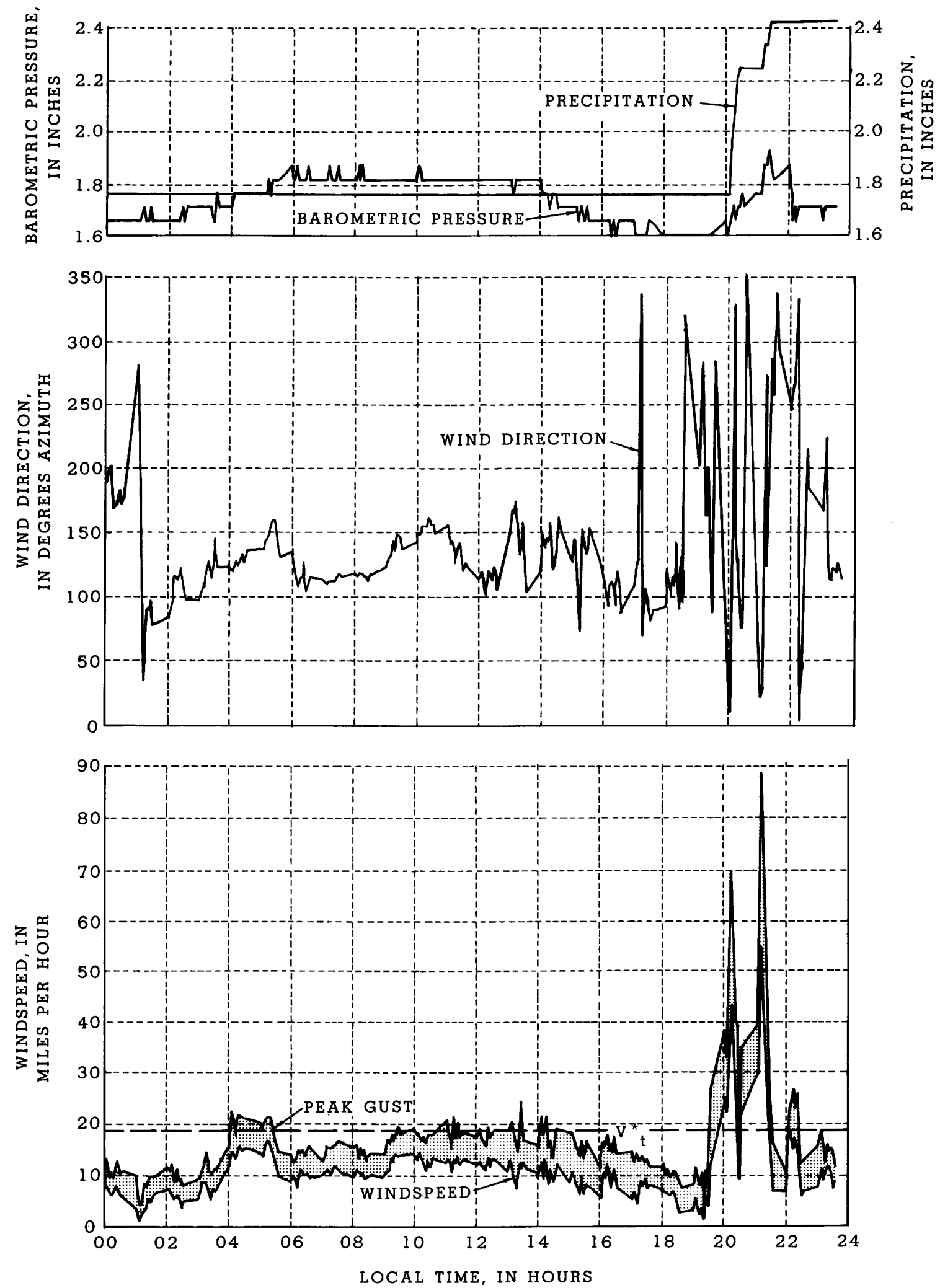

Figure 13. Condensed display of meteorologic data from Vicksburg Geomet station for August 8, 1981. This storm differed from Gold Spring event illustrated by figures 10 and 11 in its relative brevity and intensity and in its evening rather than midday occurrence. Fluid-threshold velocity $\underline{v}_{t}^{*}$ (Bagnold,
1941) for eolian transport of average-size dune sand at this locality is approximately $8.5 \mathrm{~m} / \mathrm{s}$ (heavy dashed line). Note increase in precipitation shortly after onset of extremely high winds after 1900 l.s.t.; this pattern is typical of desert "haboobs" (Idso, 1976). 
of the roof were scattered over a distance of about $0.4 \mathrm{~km}$ to the east of the house and came very close to our Geomet station. According to Mrs. Grace Lowe, who provided the eyewitness report given below, a tornado hit the house, but there was so much dust and confusion that it is uncertain whether a funnel cloud was actually present.

The station was essentially undamaged, but the legs of the frame were noticeably sandblasted to a height of about a meter on their west-facing sides. New granule ripples with a spacing of about $10 \mathrm{~cm}$ were observed on the formerly flat pea gravel near the station. In addition, the scattered ground shrubs in the area were stripped clean of their leaves. Although the data from this event were recorded and transmitted by the station, they were lost somehow in the downlink transmission from GOES to the NESS receiving facility.

Two days after Billingsley's visit, another storm hit the area and overturned one of the two house trailers being used by the Lowe family as temporary shelter. The data from this event (fig. 13) were received by telemetry and showed peak gusts of almost $144 \mathrm{~km} / \mathrm{h}$ accompanied by extreme variation in wind direction and, during an interval of little more than an hour, $1.5 \mathrm{~cm}$ of precipitation. Another storm hit between 2300 l.s.t. August 10 and 0200 l.s.t. August 11 , this one from the east. Our records show peak gusts of about $80 \mathrm{~km} / \mathrm{h}$, with winds of more than 48 $\mathrm{km} / \mathrm{h}$ over at least a 3-hour period. No further damage was reported by the Lowes, possibly because everything in the vicinity was so badly damaged already.

The following eyewitness account by Mrs. Lowe of some of the events that affected the Vicksburg area was provided in a letter dated August 17, 1981, to G. H. Billingsley.

First I'l explain about the storm which hit us on July 10 th at about 4:20 p.m. It came out of the west, and when the wind got wild it came in all directions. The kids and I were in the house when the roof came off. We heard the wind come up, then the windows broke out on the west side of the house, then the doors started slamming, then opened and slammed shut again. It was raining very hard when the roof came off. We ran outside to the pick-up and sat there for about $2-1 / 2 \mathrm{hrs}$. until the rain stopped. At one time it stopped raining like someone turned off a faucet for about 5 to 10 minutes, when it started again the wind seemed stronger, and it rocked the truck from side to side $* * *$.

Well, we were just getting settled in the trailer when on August 8th about 7:00 p.m. we were hit with another storm, which came out of the northeast and did the same as the last one. It lasted about 2 hrs. and, would you believe it, flipped the trailer on its side. We are finally getting settled again. On the 10th of Aug. we had another windstorm, not much rain but a lot of wind which came out of the east. Surprisingly, no damage this time.
This series of storms that struck the Vicksburg area provides a very different meteorologic picture from that of the storms which affected the Gold Spring area, as typified by the event on March 26, 1981. The Gold Spring storm (fig. 11) was marked by a gradual increase in wind intensity (with peak gusts exceeding $96 \mathrm{~km} / \mathrm{h}$ toward midday and a gradual decrease to velocities below $V_{t}^{*}$ (fluid threshold) at night. During the height of this storm, the wind direction was relatively constant from the westsouthwest, parallel to the axial trend of the linear dunes that characterize the Gold Spring area; there was no measurable precipitation.

The Vicksburg storms, however, were more short lived, more intense, less rhythmic diurnally, and varied more widely in wind direction (fig. 13). The Vicksburg data are consistent with those expected from the passage of "haboobs," described in Arizona and elsewhere by Idso (1976). This type of storm is commonly caused by downdrafts of cool air from a single large cumulonimbus cloud. The density current generated by the relatively small scale disturbances creates a highly turbulent, churning near-ground flow pattern that commonly causes small whirlwinds which can damage buildings. Loose dust is picked up into a towering mass of cool air, within which visibility is generally a few hundred meters or less. Passage of the cool turbulent downdraft is commonly followed by a period of short but intense precipitation (fig. 13). Local storms of this type are reported about a dozen times per year in the vicinity of Phoenix.

To begin to assess the geologic responses of various desert surfaces to complex meteorologic processes, a theoretical measure of the potential sandmoving capacity of the wind has been developed (D. J. MacKinnon and others, unpub. data, 1984). Figure 14 shows some preliminary results of this work. The upper bar graph represents the daily total potential mass of sand that the measured wind might be capable of transporting across a 1-cm-wide line perpendicular to the wind's direction, under ideal conditions (absence of soil moisture and vegetation). The total potential sand-moving capacity of the wind for each day is derived from the empirical Lettau and Lettau sandflux equation (Fryberger and Dean, 1979, p. 145), into which has been mathematically folded the measured wind data; these data have been Gaussianly distributed about the average, with a variance proportional to the peak-gust speed for each measurement, and accumulated for each day. This modified sand-flux equation incorporates the sand-grain-size-distribution information for each Geomet site. Figure 14 also shows the daily total precipitation (in millimeters) on the lower bar graph. Precipitation data are included to provide quick recognition of the presence of soil moisture, which affects the cohesion of sand particles; soil moisture is a major factor that affects the movement of sand by wind (Chepil, 1956). Soil moisture remains difficult to measure directly and is not included among the parameters presently measured by Geomet stations.

The primary use of an erosion-potential chart is to screen large amounts of data so that events of potential sand-moving significance can be identified for detailed graphic treatment and analysis (figs. 12, 13). The long-term purpose of more complete models 


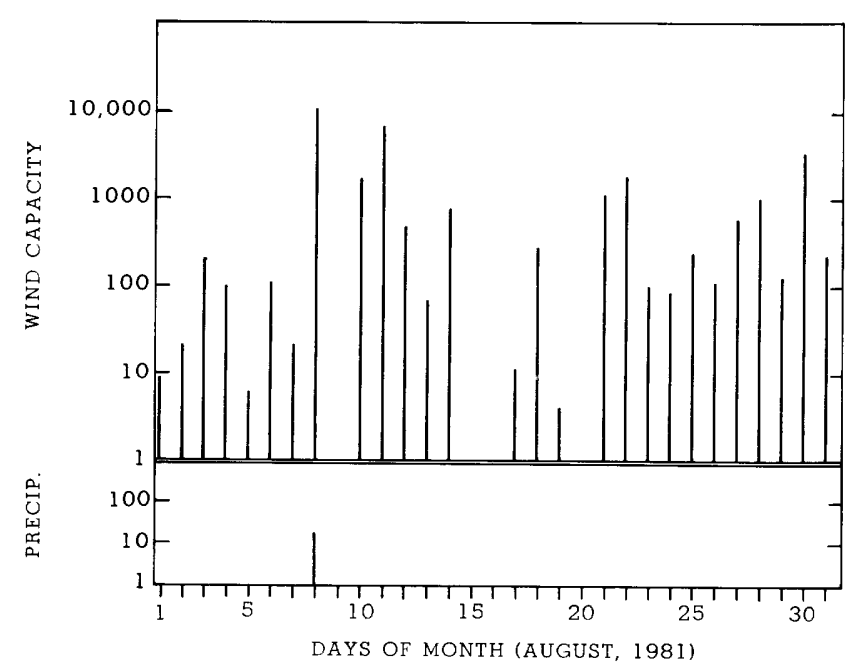

Figure 14. Erosion-potential semilog chart showing daily precipitation (in millimeters) and total daily theoretical capacity of winds to move sand (in grams per centimeter) in August 1981 at Vicksburg, Ariz., Geomet site. Compare graphs of wind capacity and precipitation for August 8 with those of meteorologic data (fig. 13) that show occurrence of precipitation in relation to highest windspeeds and peak gusts.

will be to compare the potential wind capacity predicted by a theory, such as is illustrated by figure 14, with the actual movement of sand and dust detected by the flux sensors. Differences between the theoretical and actual capacity of the measured winds at each site may then be attributed to such variables as moisture and vegetation.

\section{SUMMARY}

Although short-term measurements have been made and much local lore and speculation exist about wind processes in deserts, the need for long-term quantitative studies in these regions has been neglected. The less arid regions are far better understood in terms of the geologic processes that shape their surfaces. Throughout geologic time but more demonstrably in the recent past, deserts have cyclically expanded and contracted. Their present-day expansion, due to natural causes abetted by human misuse of marginal areas (desertification), threatens the productivity of the American West (Sheridan, 1981).

Our Geomet monitoring system should help provide detailed quantitative data on wind behavior in relation to other parameters in various desert environments. The automatic solar-powered highresolution stations can be emplaced in truly remote desert areas of special interest. Once operational, these low-maintenance stations are not constrained by periodic service requirements and laborious analog data-reduction procedures.

Our immediate objective is a long-term study of the geologic role of wind, relative to other geologic agents, in the five distinctive desert regions of
Arizona, using our data-collection platforms coupled with an array of off-the-shelf meteorologic devices. This relatively low-cost, non-labor-intensive array could be expanded later, as necessary, to address desertification problems in the American West as a whole.

Four of our Geomet stations in Arizona are now operational: at Gold Spring on the Navajo Reservation; near Vicksburg, on the Ranegras Plain west of Phoenix; near Yuma; and at Red Lake. Each station was located after extensive site studies; detailed mapping of the surficial geology around each site has been completed or is in progress. Photographic stations have been established on various surficial units around each station to provide longterm repetitive coverage of physical changes and their relation to the Geomet data.

Although the U.S. Geological Survey's computer facilities in Flagstaff, Ariz., record the complete time histories of the meteorology at each station, our emphasis, to date, has been on severe windstorms. We have discussed here the results of two diverse types of windstorms, each in a different desert environment. We are currently planning to fit all our stations with sand- and dust-flux sensors to help assess the geologic effects of each event. Measured amounts of sand and dust flux produced under monitored meteorologic and geologic conditions will then be used to test the equations of wind transport based on theoretical considerations.

Analyses of quantitative meteorologic data, acquired over several years, will be combined with detailed geologic field studies and repetitive photographic coverage at each Geomet site to provide a basis for comparing wind effectiveness in deserts of differing geologic and climatic types. These quantitative data, unlike those obtained by existing weather stations, should be of sufficient resolution and timespan to contribute to a better understanding of desert processes in general and of the role of wind in particular. Varying patterns of wind activity and surface response are already evident from the data recorded from the various subtypes of the Arizona desert being monitored. These differences indicate the complexity of desert environments in general and the difficulty of applying any single theoretical or experimental model to the formation of desert landforms.

\section{REFERENCES CITED}

Bagnold, R. A., 1941, The physics of blown sand and desert dunes: London, Chapm an and Hall, 265 p.

Breed, C. S., Fryberger, S. C., Andrews, Sarah, McCauley, C. K., Lennartz, Frances, Gebel, Dana, Horstman, Kevin, 1979, Regional studies of sand seas using Landsat (ERTS) imagery, in McKee, E. D., ed., A study of global sand seas: U.S. Geological Survey Professional Paper 1052, p. 305-397.

Breed, C. S., McCauley, J. F., Breed, W. J., Billingsley, G. H., and McCauley, C. K., 1983, Eolian landscapes, in Smiley, T. L., and others, eds., Landscapes of Arizona-the geologic story: New York, Academic Press [in press]. 
Chepil, W. S., 1956, Influence of moisture on erodibility of soil by wind: Soil Science Society Proceedings; v. 20, no. 2, p. 288-292.

Cotera, A. S., and McCauley, C. K., 1977, Comparative analysis of fluvial versus aeolian sources for wind deposits abs., in Eolian processes, chap. 7 of Arvidson, R. E., and Wahmann, compilers, Reports of Planetary Geology Program, 1976-1977: U.S. National Aeronautics and Space Administration Technical Memorandum TM X-3511, p. 153-154.

Fryberger, S. G., Ahlbrandt, T. S., and Andrews, Sarah, 1979, Origin, sedimentary features, and significance of low-angle eolian "sand sheet" deposits, Great Sand Dunes National Monument and vicinity, Colorado: Journal of Sedimentary Petrology, v. 49, no. 3, p. 733-749.

Fryberger, S. G., and Dean, Gary, 1979, Dune forms and wind regime, in McKee, E. D., ed., A study of global sand seas: U.S. Geological Survey Professional Paper 1052, p. 137-169.

Goldsmith, Victor, 1973, Internal geometry and origin of vegetated coastal sand dunes: Journal of Sedimentary Petrology, v. 43, no. 4, p. 11281142.

Haynes, C. V., Jr., 1980, Quaternary geology and archaeological observations, in El-Baz, Farouk, Boulos, L., Breed, C. S., Dardir, A. A., Dowidar, H., El-Etr, H. A., Embabi, N. S., Grolier, M. J., Haynes, C. V., Jr., Ibrahim, M. W., Issawi, B., Maxwell, T. A., McCauley, J. F., McHugh, W., Moustafa, A. R., and Yousif, M. S. M., Journey to the Gilf Kebir and Uweinat, Southwest Egypt, 1978: Geographical Journal, v. 146, no. 1, p. 5963.

Idso, S. B.. 1976, Dust storms: Scientific American, v. 235, no. 4, p. 108-114.

Krinsley, D. H., Marshall, John, McCauley, J. F., Breed, C. S., and Grolier, M. J., 1981, Production of fine silt and clay during natural eolian abrasion abs., in Aeolian processes and landforms, chap. 5 of Holt, H. E., compiler, Reports of Planetary Geology Program--1981: U.S. National Aeronautics and Space Administration Technical Memorandum 84211, p. 251-254.

Lyles, Leon, 1976, Wind patterns and soil erosion on the Great Plains, in Tinus, R. W., ed., Shelterbelts on the Great Plains: Great Plains Agricultural Council Publication 78, p. 22-30.

McCauley, C. K., and Breed, W. J., 1980, Topographically controlled dune systems on Earth and Mars abs., in Aeolian processes and landforms, chap. 6 of Wirth, P., Greeley, Ronald, and D'Alli, R. E., compilers, Reports of Planetary Geology Program, 1979-1980: U.S. National Aeronautics and Space Administration Technical Memorandum 81776, p. 255-256.

McCauley, J. F., Breed, C. S., El-Baz, Farouk, Whitney, M. I., Grolier, M. J., and Ward, A. W., 1979a, Pitted and fluted rocks in the Western Desert of Egypt-Viking comparisons: Journal of Geophysical Research, v. 84, no. B14, p. 82228232.

McCauley, J. F., Breed, C. S., Grolier, M. J., and
MacKinnon, D. A., 1981, The U.S. dust storm of February 1977, in Pewe, T. L., ed., Desert dust: Origin, characteristics, and effect on Man: Geological Society of America Special Paper 186, p. 123-147.

McCauley, J. F., Breed, C. S., Grolier, M. J., Whitney, M. I., Ward, A. W., and Greeley, Ronald, 1979b, Wind tunnel simulation studies of airflow patterns around pitted and fluted ventifacts from the Western Desert of Egypt abs., in Eolian processes, chap. 6 of Boyce, J. M., and Collins, P. S., compilers, Reports of Planetary Geology Program, 1978-1979: U.S. National Aeronautics and Space Administration Technical Memorandum 80339, p. 288-289.

McCauley, J. F., Grolier, M. J., and Breed, C. S., 1977, Yardangs, in Doehring, D. O., ed., Geomorphology in arid regions: Annual Geomorphology Symposium, 8th, Binghamton, N.Y., 1977, Proceedings, p. 233-269.

McKee, E. D., 1979a, Ancient sandstones considered to be eolian, in McKee, E. D., ed., A study of global sand seas: U.S. Geological Survey Professional Paper 1052, p. 187-238.

$1979 \mathrm{~b}$, Sedimentary structures in dunes, in McKee, E. D., ed., A study of global sand seas: U.S. Geological Survey Professional Paper 1052, p. 83-134.

McKee, E. D., and Douglass, J. R., 1971, Growth and movement of dunes at White Sands National Monument, New Mexico, in Geological Survey research, 1971: U.S. Geological Survey Professional Paper 750-D, p. D108-D114.

Metzger, D. G., Loeltz, O. J., and Irelna, Burdge, 1973, Geohydrology of the Parker-Blythe-Cibola area, Arizona and California: U.S. Geological Survey Professional Paper 486-G, p. G1-G130.

Olson, J. W., 1979, Desert glass: Aramco Magazine, v. 30 , no. 5 , p. 2-5.

Pimentel, David, Terhune, E. C., Dyson-Hudson, Rada, Rochereau, Stephen, Samis, Robert, Smith, E. A., Denman, Daniel, Reifschneider, David, and Shepard, Michael, 1976, Land degradation: effects on food and energy resources: Science, v. 194 , no. 4261 , p. 149-155.

Reiche, Parry, 1938, An analysis of cross-laminationthe Coconino Sandstone: Journal of Geology, v. 46, no. 7, p. 905-932.

Sheridan, David, 1981, Desertification of the United States: Washington, U.S. Government Printing Office, $142 \mathrm{p}$.

Whitney, M. I., 1978, The role of vorticity in developing lineation by wind erosion: Geological Society of America Bulletin, v. 89, no. 1, p. 1-18.

Wilshire, H. G., Nakata, J. K., and Hallett, Bernard, 1981, Field observations of the December 1977 windstorm, San Joaquin Valley, California, in Pewe, T. L., ed., Desert dust: Origin, characteristics, and effect on Man: Geological Society of America Special Paper 186, p. 233251.

Windom, H. L., and Chamberlain, C. F., 1978, Duststorm transport of sediments to the North Atlantic Ocean: Journal of Sedimentary Petrology, v. 48, no. 2, p. 385-388. 
by

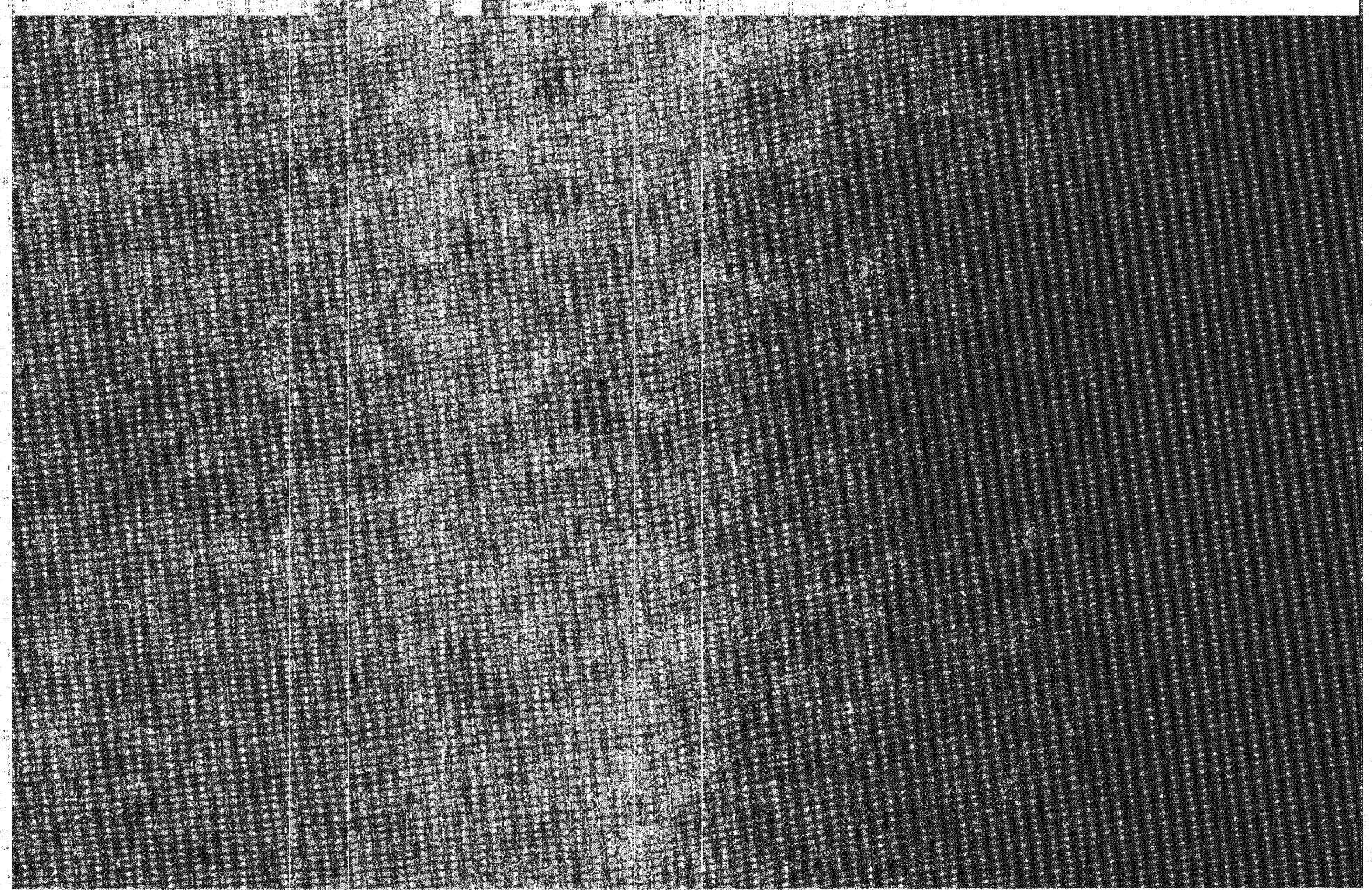

